University of Warwick institutional repository: http://go.warwick.ac.uk/wrap This paper is made available online in accordance with publisher policies. Please scroll down to view the document itself. Please refer to the repository record for this item and our policy information available from the repository home page for further information.

To see the final version of this paper please visit the publisher's website. Access to the published version may require a subscription.

Author(s): NICHOLAS CRAFTS and ABAY MULATU

Article Title: How Did the Location of Industry Respond to Falling Transport Costs in Britain Before World War I?

Year of publication: 2006

Link to published version: http://dx.doi.org/

10.1017/S002205070600026X

Publisher statement: None 


\title{
How Did the Location of Industry Respond to Falling Transport Costs in Britain Before World War I?
}

\author{
NiCHOLAS CRAFTS AND ABAy MULATU
}

This article explores the location of industry in pre-World War I Britain using a model that takes account both of factor endowment and also of New Economic Geography influences. Broadly speaking, the pattern of industrial location in this period was quite persistent and regional specialization changed little. The econometric results show that factor endowments had much stronger effects than proximity to markets, although the latter was an attraction for industries with large plant size. Overall, falling transport costs had relatively little effect on industrial location at a time when proximity to natural resources, notably coal, mattered most.

$\mathrm{T}^{\mathrm{h}}$ he nineteenth-century British economy is often described in terms of a North-South divide. Regional specialization is usually explained in terms of endowments of coal and its attraction to the Victorian staple industries for which it was an important input because of steam power. ${ }^{1}$ At least until the railway age, there were pronounced differences in coal prices in different localities, with the most expensive about six times the cheapest. $^{2}$ It is generally accepted that the basic pattern of industrial location was established during the canal era and not seriously disturbed by the advent of the railway. ${ }^{3}$ Certainly, once established, industries benefited from external economies, but for mid-century, proximity to natural resources rather than to markets is the major theme in the literature. ${ }^{4}$

At some point late in the nineteenth or early in the twentieth century a different rationale for industrial location started to emerge. Once electricity became available as an alternative source of power, industry had

The Journal of Economic History, Vol. 66, No. 3 (September 2006). (C) The Economic History Association. All rights reserved. ISSN 0022-0507.

Nicholas Crafts is Professor of Economic History, University of Warwick, Coventry CV4 7AL, UK. E-mail: n.crafts@warwick.ac.uk. Abay Mulatu is Research Fellow at the CambridgeMIT Institute, Mill Lane Cambridge, CB32 1RQ. E-mail: a.mulatu@cmi.cam.ac.uk.

Financial support from the Economic and Social Research Council under Grant R000239536 is gratefully acknowledged. We would like to thank Steve Redding, the editor, and an anonymous referee for helpful comments on an earlier version of this article. Any remaining errors are ours.

${ }^{1}$ See, for example, Langton and Morris, "Introduction"; Lee, Regional Economic Growth; and Pollard, Peaceful Conquest.

2 von Tunzelmann, "Coal."

${ }^{3}$ Gourvish, Railways, p. 31.

${ }^{4}$ Hudson, "Regional Perspective." 
more freedom to move away from coalfields, and increasingly complex products and mass production techniques came to the fore. ${ }^{5}$ These developments are seen as encouraging manufacturing firms to favor central locations close to key suppliers and well-placed to serve large markets. Marked changes in the location of engineering and vehicles are seen as characteristic of these tendencies. ${ }^{6}$ This perspective resembles that of the New Economic Geography, whereas the traditional account of the nineteenth-century economy is more akin to the predictions of a Heckscher-Ohlin model based on factor endowments. ${ }^{7}$

The descriptions in the British historiography are informal both in the sense that they are not grounded in economic theory nor have they been formulated as testable hypotheses and subjected to quantitative scrutiny. This is in sharp contrast with the economic history of American industrialization. ${ }^{8}$ In particular, despite continual discussion of the role of transport costs in the spatial distribution of economic activity, there has been no examination of this in a framework of general equilibrium analysis.

The New Economic Geography has formalized a number of propositions regarding the pull of centrality that are of interest in this context. At bottom, these can be summarized as predictions that when transport costs are very high or very low, economic activity will be spatially dispersed, but when transport costs enter an intermediate zone, firms' location decisions involve consideration of market access as well as production costs. When transport costs are "intermediate," it may be advantageous to locate near to industrial customers, and suppliers and increasing-returns industries may also prefer to locate their (large) plants at central locations. ${ }^{9}$

Thus, at some point, falling transport costs supplement the factor endowment arguments with a market access explanation of industrial location. This could happen in the context of improvements to an existing transport technology rather than awaiting the introduction of a new mode. So, although the increasing attraction of central locations and the diminishing appeal of outer Britain has often been linked to the arrival of motorized road haulage, continuing reductions in the cost of rail freight and coastal shipping may eventually have had similar implications. Regional market potential is fundamental to the pull of centrality, and this was increasing at a varying pace across British regions as

\footnotetext{
${ }^{5}$ Lee, Regional Economic Growth.

${ }^{6}$ Dennison, Location of Industry; and Hume and Oglethorpe, "Engineering."

${ }^{7}$ For the former see Venables, "Equilibrium Locations"; and for the latter, Richardson and Smith, "Sectoral Growth."

${ }^{8}$ Kim, "Economic Integration" and "Regions."

${ }^{9}$ Venables, "Equilibrium Locations."
} 
World War I approached and both regional incomes and also the proximity of foreign markets were exposed to globalization. ${ }^{10}$

Looking at the economy through this lens might have ramifications for the measurement of economic benefits from transport improvements. Gary Hawke, who estimated the social savings of railways, explicitly recognized this as follows: "If as a result of the establishment of railways, a particular industry became more concentrated geographically, and if this resulted in a lowering of the real costs of that industry, then the establishment of the railways has given the economy the equivalent of extra resources. The railways have then contributed to economic growth in a way that is not reflected in the social saving."11 These are exactly the impacts envisaged by the New Economic Geography, and simulations of calibrated models of this type suggest that total economic benefits might easily be much larger than the transport benefits. ${ }^{12}$ Looking at the early decades, Hawke concluded that his social saving estimate did not need to be adjusted to allow for such externalities because the location of industry was not affected by the advent of the railway. ${ }^{13}$

An alternative way to estimate the contribution of a new technology to economic growth would be to use growth accounting techniques. In that context, the cost reductions that flowed from induced decreases in the real costs of transport-using industries would be reckoned as spillover effects on total factor productivity (TFP) growth. Nicholas Crafts recently examined the impact of steam (including both railways and steamships as well as stationary steam engines) on British economic growth using a methodology of this kind. ${ }^{14} \mathrm{He}$ found that the main impact of steam was felt after 1850 but was unable to include TFP spillovers in his analysis. However, he noted that if steam-powered transport had effects of this kind it would strengthen this finding with respect to the chronology of steam's contribution to growth.

In the light of this discussion, in the rest of the article we provide a description and econometric analysis based on a reduced form equation derived from a general equilibrium model of the location of industrial employment at the two-digit level for Britain in the decades from the railway age to World War I. This is used to address the following questions: What happened to the location of industry over time? What happened to market potential as globalization impinged on the economy? Is

\footnotetext{
${ }^{10}$ Crafts, "Market Potential." For the definition of market potential and some estimates, see below.

${ }^{11}$ Hawke, Railways, p. 382.

${ }^{12}$ Venables and Gasiorek, "Welfare Implications."

${ }^{13}$ Ibid., pp. 392-95.

${ }^{14}$ Crafts, "Steam."
} 
there evidence that the location of industry responded to the pull of centrality as transport costs fell? What implications are there for measurement of the contribution of steam-based transport to economic growth?

\section{REGIONAL SPECIALIZATION}

How did regional specialization evolve in the period 1841 to 1911 and how different was this experience from that of the post-1945 economy whose freight transport was dominated by road haulage rather than railways and coastal shipping? The context for this enquiry is set out in Table 1 , which shows the extent to which the share of manufacturing in total employment differed across regions and provides a breakdown of the sectoral composition of employment within manufacturing. The table shows that the British economy was still industrializing through 1911, at which point the highest shares of manufacturing were in the North West, West Midlands, and Yorkshire and Humberside whereas the south, with the exception of London, was much less industrial. By 1971, this "North-South divide" was still clearly visible but much less pronounced. A notable feature of the pre-1911 economy was the tendency for a high fraction of manufacturing in a region to be in one sector; there are 13 instances of a sector comprising more than 20 percent of manufacturing employment before 1911 compared with only one in 1971.

Regional shares of employment in the total for each industry (which in logarithmic form will be the dependent variable for our econometric analysis) are set out in Table 2. The overall picture is of quite modest changes but one or two relatively large shifts stand out. For example, chemicals moved steadily to North West, shipbuilding gravitated to the North and Scotland and away from South East and South West, vehicles expanded markedly in West Midlands but contracted in the southern regions. Textiles became even more concentrated in North West but declined in Scotland.

For several sectors, particular regions have persistently high location quotients including shipbuilding in North, metal manufacture in Wales, and metal goods in West Midlands. ${ }^{15}$ Of the 16 instances of a location quotient above 1.75 in 1841, nine remained in 1911 and five in 1971. However, the original reason for an industry's location may in some cases have lost its relevance; for example, woolens were originally attracted to Yorkshire by the availability of water power and supplies of raw wool but stayed because of external economies of scale in marketing, labor skills, and so on. ${ }^{16}$

\footnotetext{
${ }^{15}$ The location quotient is defined as $s_{i}^{k} / s_{\text {all }}{ }^{k}$, in other words, it compares the share of the region in employment in the $i$ th industry with its share in manufacturing employment as a whole.

${ }^{16}$ Lee, Regional Economic Growth, p. 121.
} 


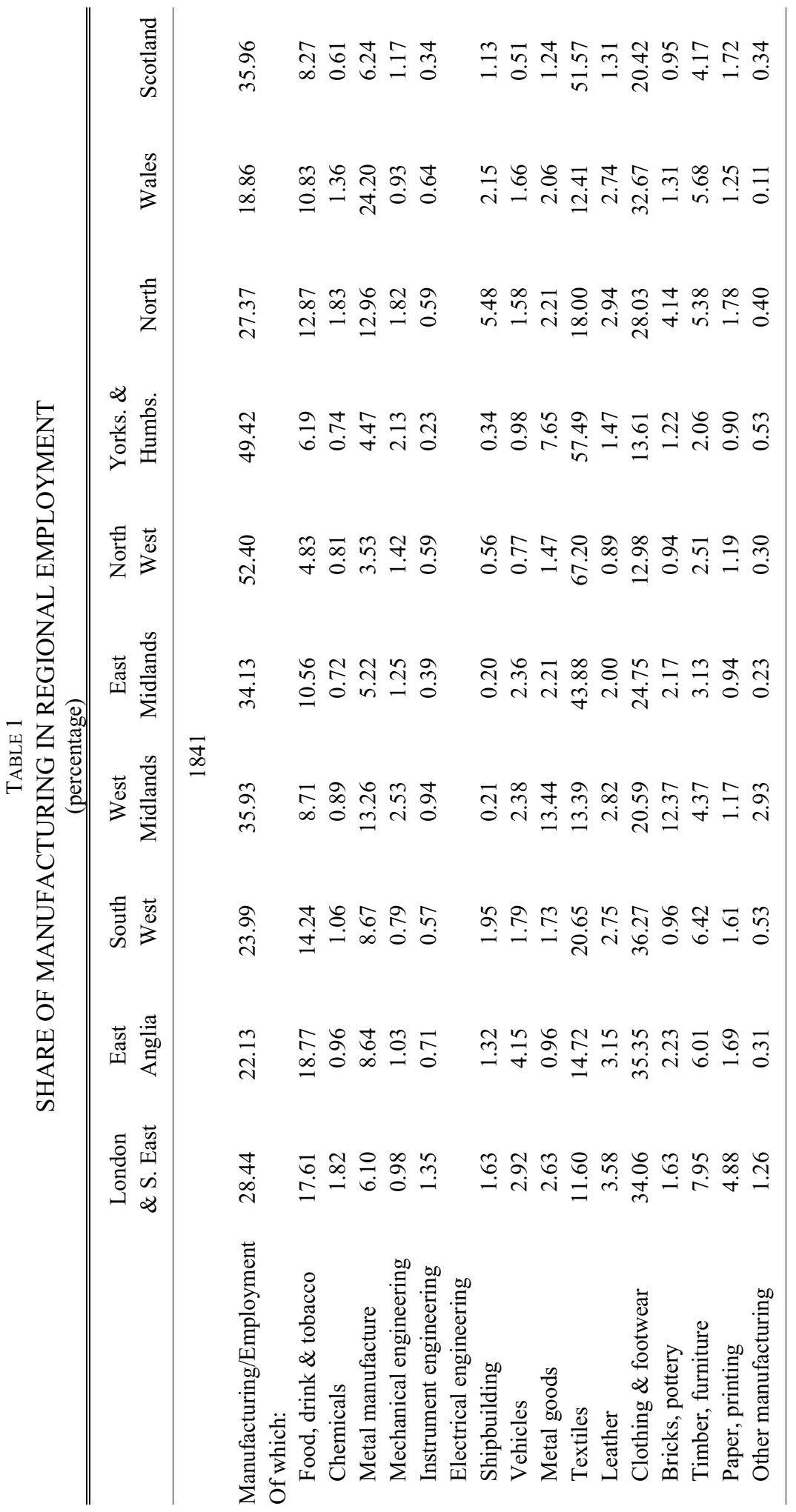




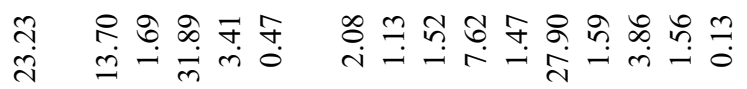

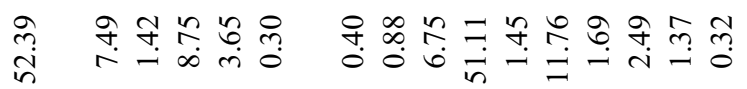

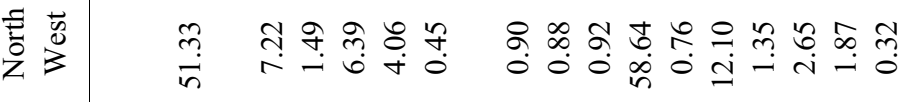

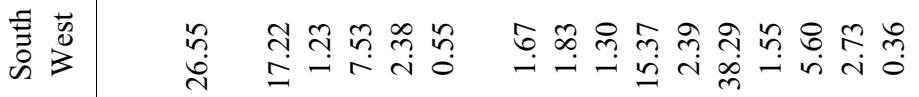

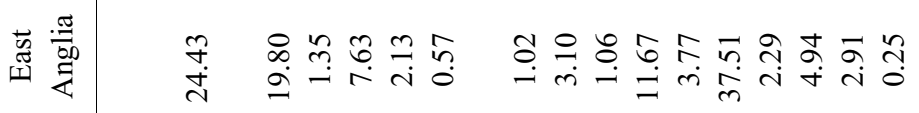

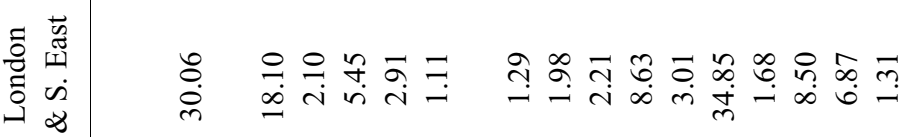

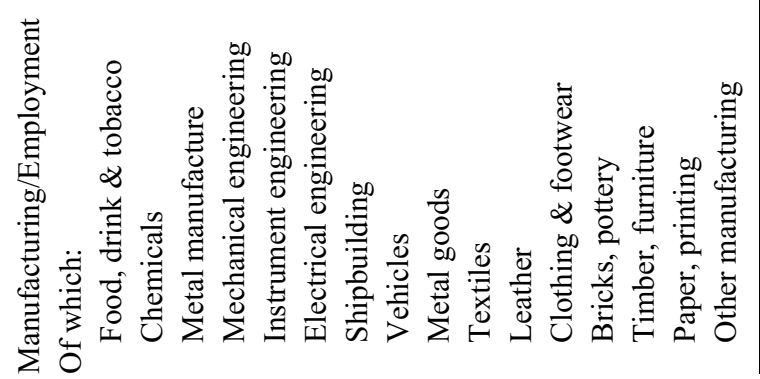




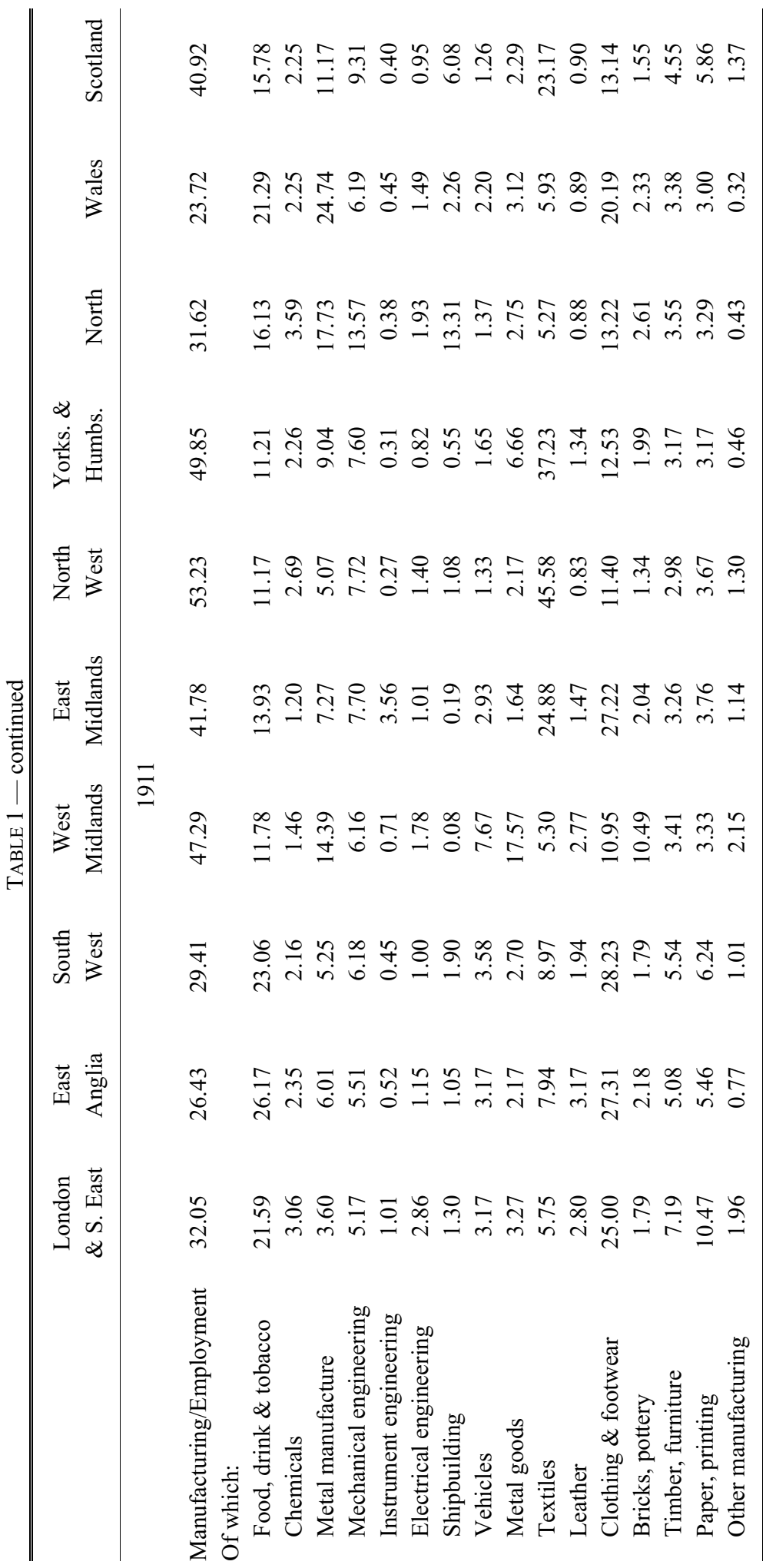




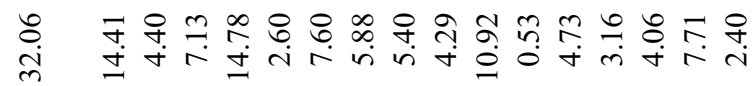

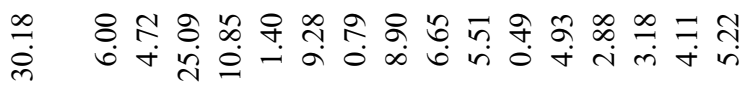

䓂

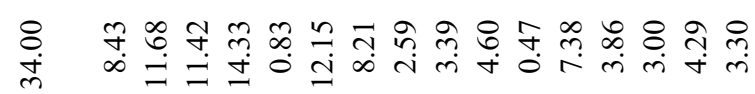

$\infty$

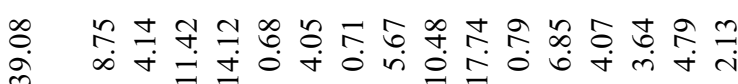

E्ञ

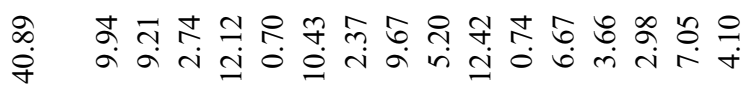

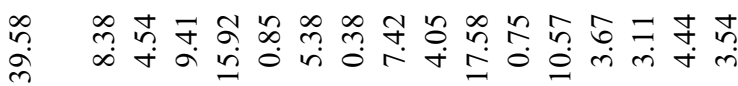

ลิ

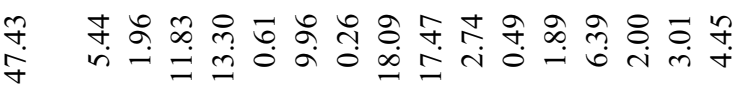

吾葡

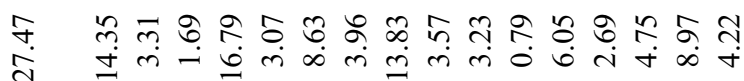

瞢

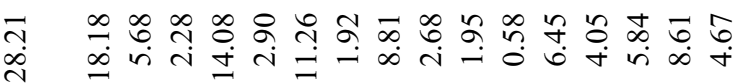

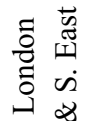

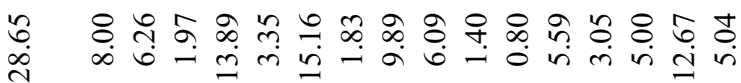




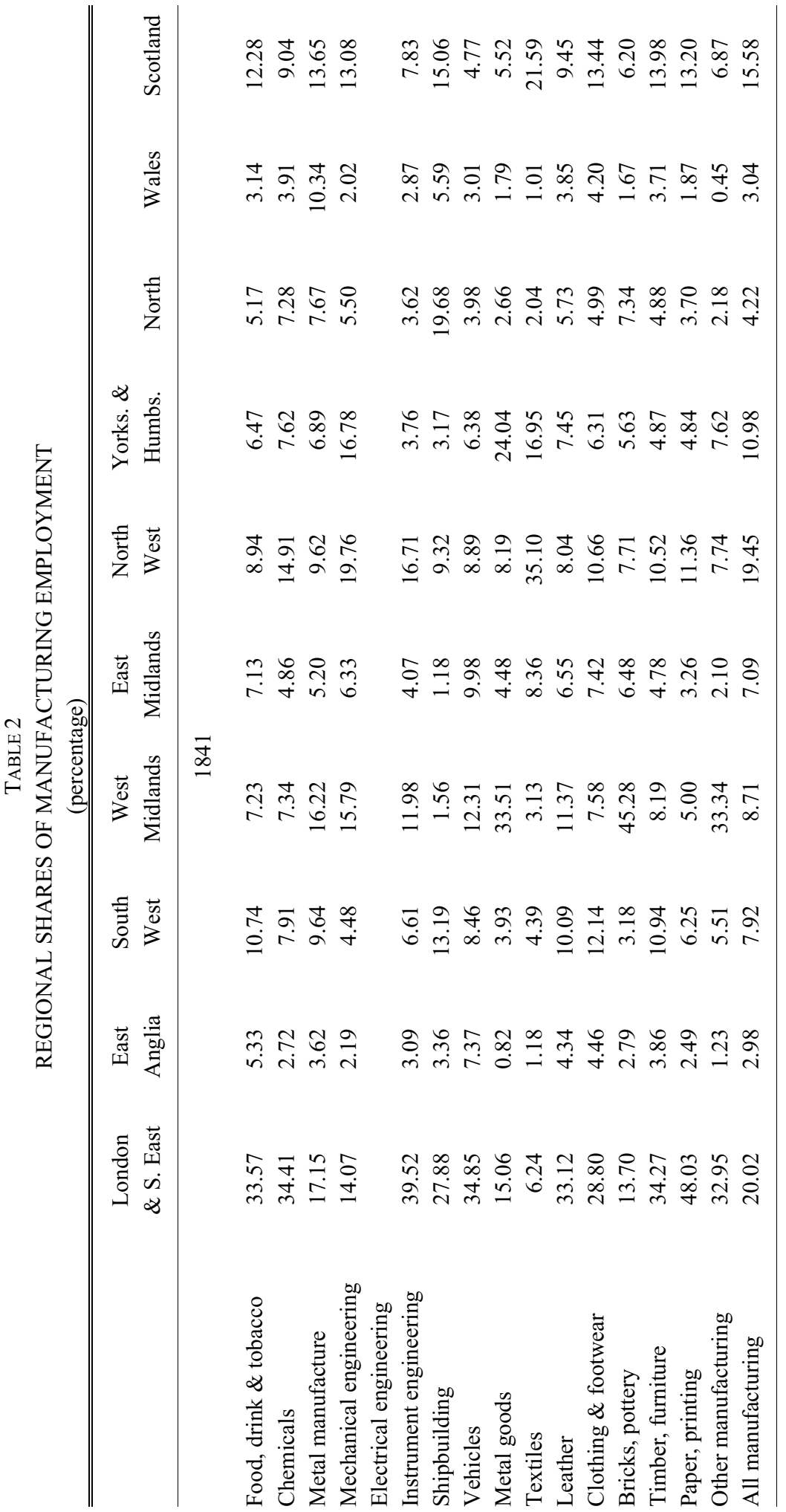




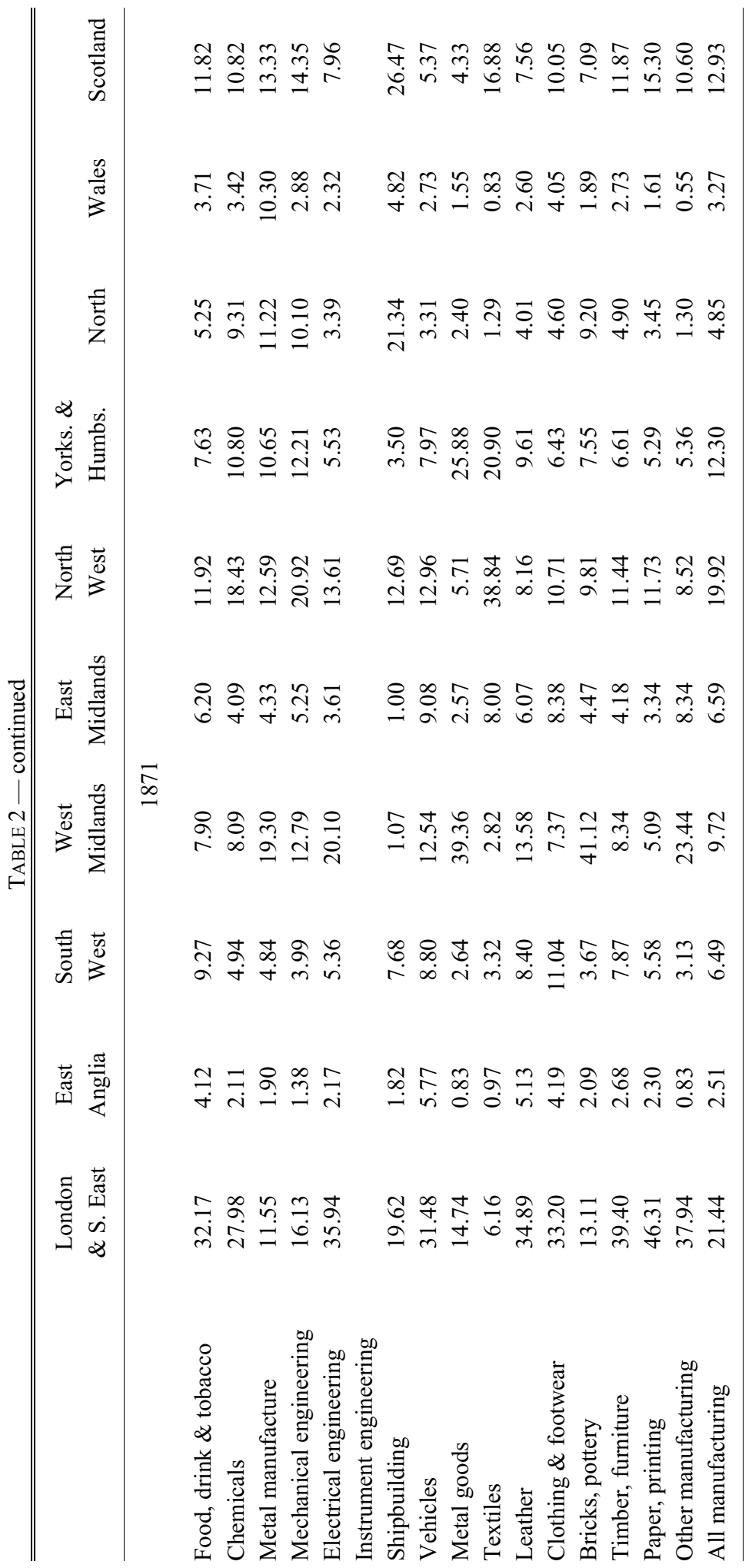




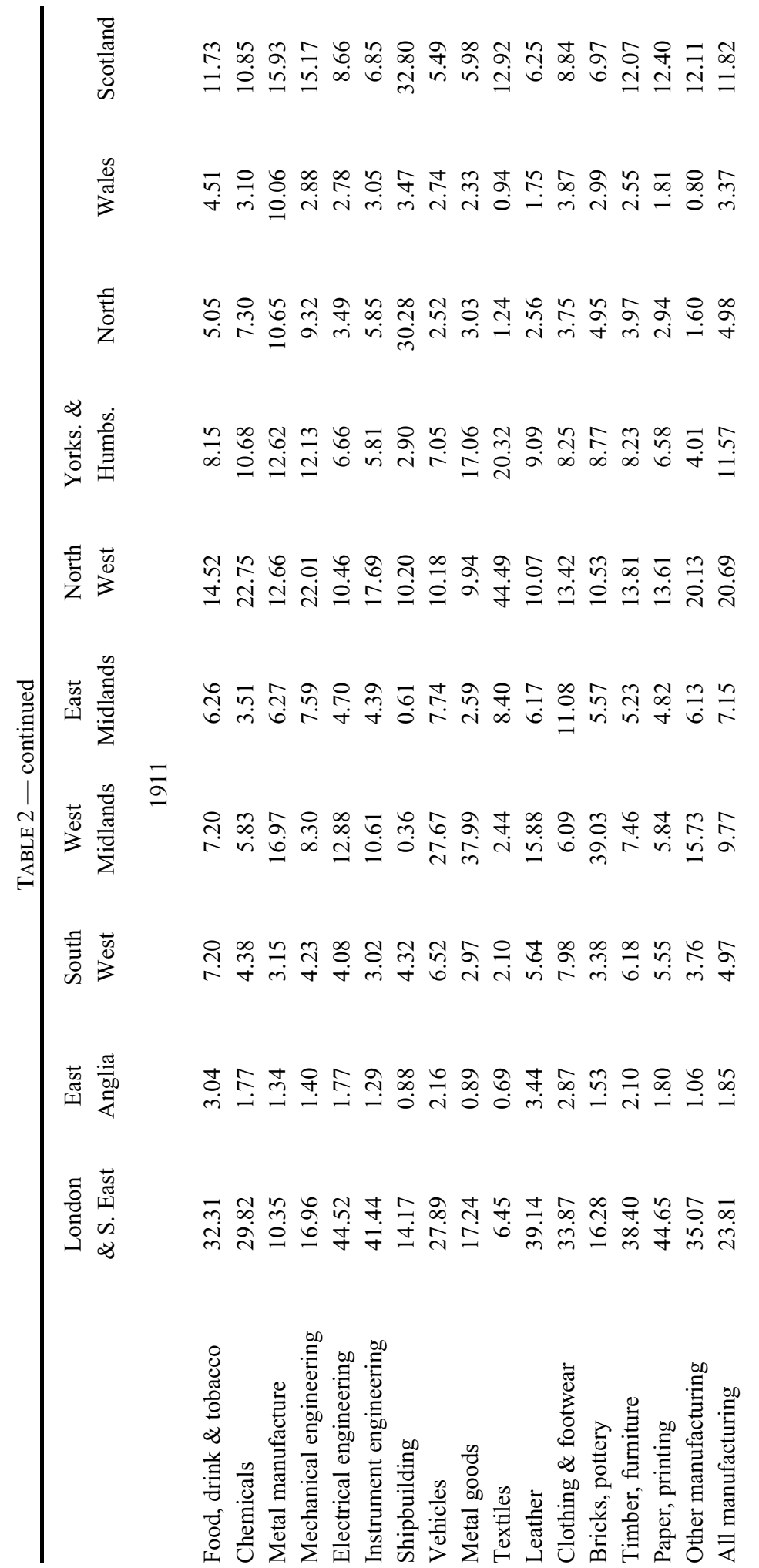




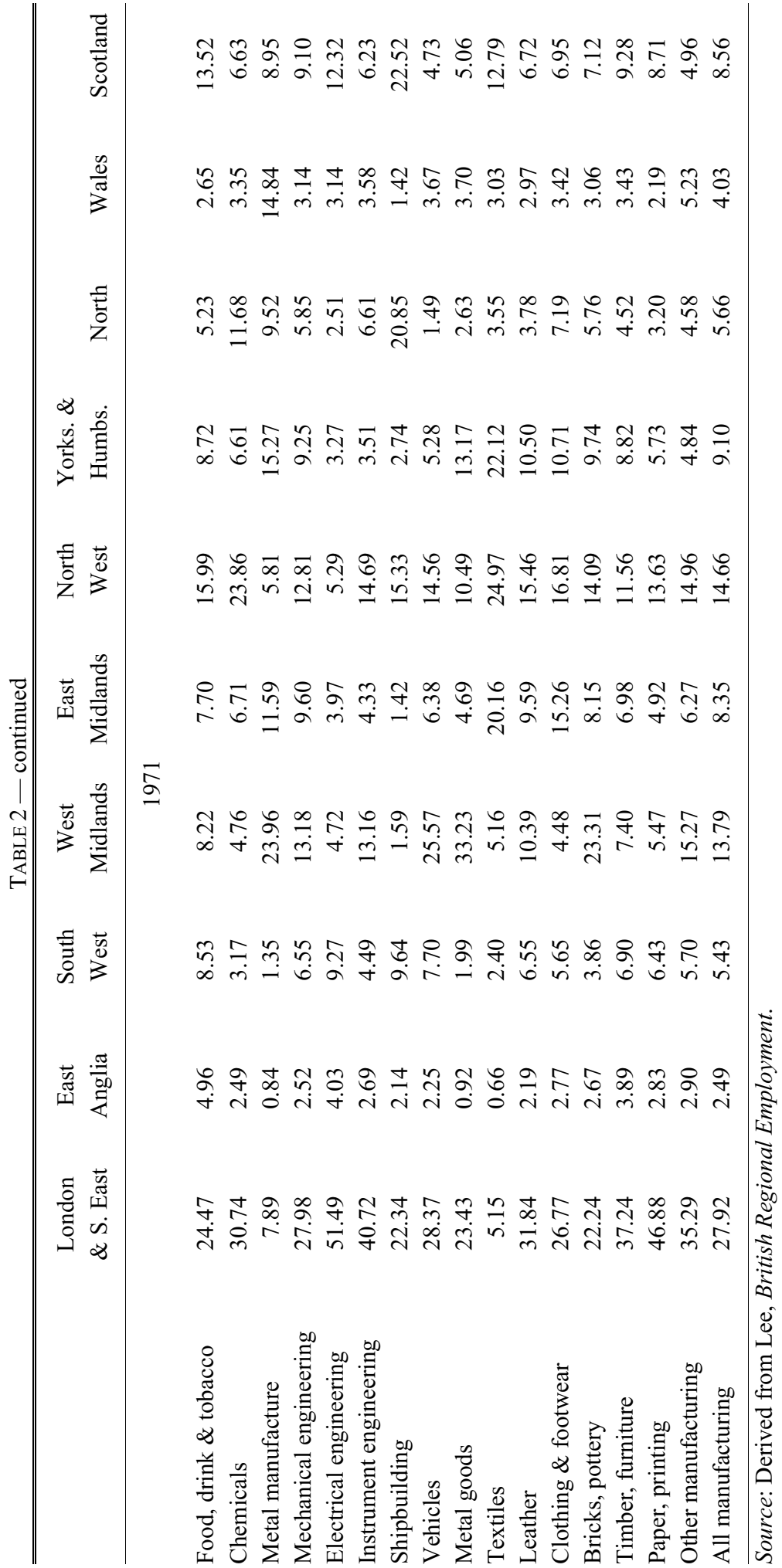


TABLE 3 INDEX OF REGIONAL SPECIALIZATION IN MANUFACTURING

\begin{tabular}{|c|c|c|c|c|}
\hline & 1841 & 1871 & 1911 & 1971 \\
\hline SE/EA & 0.20 & 0.24 & 0.25 & 0.32 \\
\hline $\mathrm{SE} / \mathrm{SW}$ & 0.28 & 0.25 & 0.23 & 0.36 \\
\hline SE/WM & 0.67 & 0.77 & 0.79 & 0.71 \\
\hline SE/EM & 0.66 & 0.59 & 0.57 & 0.64 \\
\hline SE/NW & 1.12 & 1.04 & 0.88 & 0.38 \\
\hline SE/YH & 1.04 & 1.02 & 0.86 & 0.67 \\
\hline $\mathrm{SE} / \mathrm{N}$ & 0.41 & 0.65 & 0.72 & 0.56 \\
\hline $\mathrm{SE} / \mathrm{W}$ & 0.39 & 0.55 & 0.48 & 0.58 \\
\hline $\mathrm{SE} / \mathrm{SC}$ & 0.81 & 0.77 & 0.68 & 0.53 \\
\hline SE Average & 0.62 & 0.65 & 0.61 & 0.53 \\
\hline $\mathrm{EA} / \mathrm{SE}$ & 0.20 & 0.24 & 0.25 & 0.32 \\
\hline EA/SW & 0.18 & 0.13 & 0.12 & 0.59 \\
\hline EA/WM & 0.63 & 0.78 & 0.80 & 0.74 \\
\hline EA/EM & 0.61 & 0.53 & 0.44 & 0.61 \\
\hline EA/NW & 1.07 & 0.98 & 0.82 & 0.38 \\
\hline EA/YH & 1.02 & 0.96 & 0.78 & 0.67 \\
\hline $\mathrm{EA} / \mathrm{N}$ & 0.34 & 0.64 & 0.70 & 0.54 \\
\hline EA/W & 0.36 & 0.55 & 0.44 & 0.66 \\
\hline $\mathrm{EA} / \mathrm{SC}$ & 0.75 & 0.71 & 0.57 & 0.41 \\
\hline EA Average & 0.57 & 0.61 & 0.55 & 0.50 \\
\hline $\mathrm{SW} / \mathrm{SE}$ & 0.28 & 0.25 & 0.23 & 0.36 \\
\hline SW/EA & 0.18 & 0.13 & 0.12 & 0.25 \\
\hline $\mathrm{SW} / \mathrm{WM}$ & 0.66 & 0.79 & 0.80 & 0.67 \\
\hline SW/EM & 0.52 & 0.46 & 0.43 & 0.59 \\
\hline SW/NW & 0.94 & 0.90 & 0.79 & 0.43 \\
\hline $\mathrm{SW} / \mathrm{YH}$ & 0.89 & 0.88 & 0.75 & 0.69 \\
\hline $\mathrm{SW} / \mathrm{N}$ & 0.27 & 0.64 & 0.69 & 0.60 \\
\hline SW/W & 0.34 & 0.53 & 0.43 & 0.67 \\
\hline $\mathrm{SW} / \mathrm{SC}$ & 0.63 & 0.62 & 0.56 & 0.35 \\
\hline SW Average & 0.52 & 0.58 & 0.53 & 0.51 \\
\hline WM/SE & 0.67 & 0.77 & 0.79 & 0.71 \\
\hline WM/EA & 0.63 & 0.78 & 0.80 & 0.74 \\
\hline WM/SW & 0.66 & 0.79 & 0.80 & 0.67 \\
\hline WM/EM & 0.73 & 0.83 & 0.83 & 0.71 \\
\hline WM/NW & 1.08 & 1.02 & 0.90 & 0.69 \\
\hline WM/YH & 0.88 & 0.86 & 0.72 & 0.61 \\
\hline $\mathrm{WM} / \mathrm{N}$ & 0.48 & 0.46 & 0.66 & 0.68 \\
\hline $\mathrm{WM} / \mathrm{W}$ & 0.58 & 0.58 & 0.65 & 0.56 \\
\hline $\mathrm{WM} / \mathrm{SC}$ & 0.79 & 0.75 & 0.75 & 0.77 \\
\hline WM Average & 0.72 & 0.76 & 0.77 & 0.68 \\
\hline $\mathrm{EM} / \mathrm{SE}$ & 0.66 & 0.59 & 0.57 & 0.64 \\
\hline EM/EA & 0.61 & 0.53 & 0.44 & 0.61 \\
\hline EM/SW & 0.52 & 0.46 & 0.43 & 0.59 \\
\hline EM/WM & 0.73 & 0.83 & 0.83 & 0.71 \\
\hline EM/NW & 0.49 & 0.49 & 0.52 & 0.41 \\
\hline EM/YH & 0.41 & 0.47 & 0.44 & 0.21 \\
\hline $\mathrm{EM} / \mathrm{N}$ & 0.53 & 0.76 & 0.77 & 0.48 \\
\hline EM/W & 0.67 & 0.63 & 0.64 & 0.56 \\
\hline $\mathrm{EM} / \mathrm{SC}$ & 0.23 & 0.28 & 0.40 & 0.40 \\
\hline EM Average & 0.54 & 0.56 & 0.56 & 0.51 \\
\hline
\end{tabular}


TABLE $3-$ continued

\begin{tabular}{|c|c|c|c|c|}
\hline & 1841 & 1871 & 1911 & 1971 \\
\hline$\overline{\mathrm{NW} / \mathrm{SE}}$ & 1.12 & 1.04 & 0.88 & 0.38 \\
\hline NW/EA & 1.07 & 0.98 & 0.82 & 0.38 \\
\hline NW/SW & 0.94 & 0.90 & 0.79 & 0.43 \\
\hline NW/WM & 1.08 & 1.02 & 0.90 & 0.69 \\
\hline NW/EM & 0.49 & 0.49 & 0.52 & 0.41 \\
\hline NW/YH & 0.22 & 0.19 & 0.23 & 0.46 \\
\hline $\mathrm{NW} / \mathrm{N}$ & 0.98 & 1.02 & 0.83 & 0.44 \\
\hline NW/W & 1.11 & 1.04 & 0.87 & 0.54 \\
\hline NW/SC & 0.34 & 0.40 & 0.47 & 0.38 \\
\hline NW Average & 0.82 & 0.79 & 0.70 & 0.46 \\
\hline $\mathrm{YH} / \mathrm{SE}$ & 1.04 & 1.02 & 0.86 & 0.67 \\
\hline YH/EA & 1.02 & 0.96 & 0.78 & 0.67 \\
\hline YH/SW & 0.89 & 0.88 & 0.75 & 0.69 \\
\hline YH/WM & 0.88 & 0.86 & 0.72 & 0.61 \\
\hline YH/EM & 0.41 & 0.47 & 0.44 & 0.21 \\
\hline YH/NW & 0.22 & 0.19 & 0.23 & 0.46 \\
\hline $\mathrm{YH} / \mathrm{N}$ & 0.91 & 0.97 & 0.87 & 0.51 \\
\hline $\mathrm{YH} / \mathrm{W}$ & 1.05 & 0.99 & 0.74 & 0.56 \\
\hline $\mathrm{YH} / \mathrm{SC}$ & 0.29 & 0.36 & 0.39 & 0.42 \\
\hline YH Average & 0.75 & 0.74 & 0.64 & 0.53 \\
\hline $\mathrm{N} / \mathrm{SE}$ & 0.41 & 0.65 & 0.72 & 0.56 \\
\hline N/EA & 0.34 & 0.64 & 0.70 & 0.54 \\
\hline N/SW & 0.27 & 0.64 & 0.69 & 0.60 \\
\hline N/WM & 0.48 & 0.46 & 0.66 & 0.68 \\
\hline N/EM & 0.53 & 0.76 & 0.77 & 0.48 \\
\hline N/NW & 0.98 & 1.02 & 0.83 & 0.44 \\
\hline N/YH & 0.91 & 0.97 & 0.73 & 0.51 \\
\hline N/W & 0.33 & 0.32 & 0.42 & 0.56 \\
\hline N/SC & 0.67 & 0.66 & 0.45 & 0.46 \\
\hline$N$ Average & 0.55 & 0.68 & 0.66 & 0.54 \\
\hline W/SE & 0.39 & 0.55 & 0.48 & 0.58 \\
\hline W/EA & 0.36 & 0.55 & 0.44 & 0.66 \\
\hline W/SW & 0.34 & 0.53 & 0.43 & 0.67 \\
\hline W/WM & 0.58 & 0.58 & 0.65 & 0.56 \\
\hline W/EM & 0.67 & 0.63 & 0.64 & 0.56 \\
\hline W/NW & 1.11 & 1.04 & 0.87 & 0.54 \\
\hline W/YH & 1.05 & 0.99 & 0.74 & 0.56 \\
\hline $\mathrm{W} / \mathrm{N}$ & 0.33 & 0.32 & 0.42 & 0.56 \\
\hline $\mathrm{W} / \mathrm{SC}$ & 0.80 & 0.73 & 0.59 & 0.60 \\
\hline$W$ Average & 0.63 & 0.66 & 0.58 & 0.59 \\
\hline $\mathrm{SC} / \mathrm{SE}$ & 0.81 & 0.77 & 0.68 & 0.53 \\
\hline $\mathrm{SC} / \mathrm{EA}$ & 0.75 & 0.71 & 0.57 & 0.41 \\
\hline SC/SW & 0.63 & 0.62 & 0.56 & 0.35 \\
\hline SC/WM & 0.79 & 0.75 & 0.75 & 0.77 \\
\hline SC/EM & 0.23 & 0.28 & 0.40 & 0.40 \\
\hline SC/NW & 0.34 & 0.40 & 0.47 & 0.38 \\
\hline $\mathrm{SC} / \mathrm{YH}$ & 0.29 & 0.36 & 0.39 & 0.42 \\
\hline $\mathrm{SC} / \mathrm{N}$ & 0.67 & 0.66 & 0.45 & 0.46 \\
\hline $\mathrm{SC} / \mathrm{W}$ & 0.80 & 0.73 & 0.59 & 0.60 \\
\hline SC Average & 0.59 & 0.59 & 0.54 & 0.48 \\
\hline All Average & 0.63 & 0.66 & 0.61 & 0.53 \\
\hline
\end{tabular}


TABLE 3 - continued

Source: Derived from Lee, British Regional Employment using 2-digit classification based on the formula $S I_{j k}=\Sigma / E_{i j} / E_{j}-E_{i k} / E_{k} \mid$ where $E_{i j}$ is the level of employment in industry $i$ in region $j$, $E_{j}$ is total employment in region $j$ and similarly for region $k$.

Table 3 reports Paul Krugman's index of regional specialization for each pair of regions. ${ }^{17}$ This has a maximum of two in the case of complete specialization and a minimum of zero for complete similarity. It is noticeable that for some regional pairs there was a sharp change over time. For example, South West/North become much less alike in their industrial structure while at the other end of the spectrum Wales and Yorkshire \& Humberside became much more alike during 1841 to 1911. Overall, however, the average value of the regional specialization index varies only slightly, rising a little over 1841 to 1871 from 0.63 to 0.66 and then falling back to 0.61 in 1911 . This is quite a contrast with developments in the United States where the average value of the regional specialization index rose from 0.59 in 1880 to 0.89 in $1914 .^{18}$

From 1841 to 1911 the South East, East Anglia, and South West were quite similar to each other and very different from North West, West Midlands, and Yorkshire and Humberside, again reflecting a "NorthSouth divide." By 1971 these southern regions were somewhat less similar to each other and much less different from North West, in which textiles were now less prominent. By 1971 the average value of the specialization index had fallen to 0.53 .

Table 4 reports the coefficient of localization of each industry. This differs quite considerably. Textiles were always relatively localized. The biggest increase in spatial concentration between 1841 and 1911 was in shipbuilding. On the other hand, food, drink and tobacco, leather, clothing and footwear, and timber and furniture remained dispersed throughout. Through 1911 the average coefficient of localization remained unchanged but from then to 1971 it exhibited a modest decrease.

The underlying reasons for regional specialization are to be found in the characteristics of industries and regions and in the interactions of these characteristics. Accordingly, Tables 5 and 6 set out values of the individual variables, which will be used later in our econometric work. Table 5 displays data on industrial characteristics including size of plant, and the intensities of use of white-collar workers and of steam power. It also reports on linkages to other industries in terms of extent of intermediate input use and of sales to industrial users. With regard to industrial characteristics, we are reliant on the 1907 Census of Production and the input-output table for that year constructed by Mark

${ }^{17}$ Krugman, Geography.

${ }^{18} \mathrm{Kim}$, "Expansion of Markets," table 1. 
TABLE 4 LOCALIZATION INDICES

\begin{tabular}{lllll}
\hline \hline & 1841 & 1871 & 1911 & 1971 \\
\hline Food, drink \& tobacco & 0.11 & 0.12 & 0.12 & 0.13 \\
Chemicals & 0.15 & 0.13 & 0.11 & 0.18 \\
Metal manufacture & 0.15 & 0.24 & 0.26 & 0.40 \\
Mechanical engineering & 0.24 & 0.21 & 0.18 & 0.08 \\
Instrument engineering & 0.24 & 0.21 & 0.20 & 0.25 \\
Electrical engineering & & & 0.18 & 0.14 \\
Shipbuilding & 0.21 & 0.30 & 0.57 & 0.34 \\
Vehicles & 0.21 & 0.14 & 0.21 & 0.19 \\
Metal goods & 0.42 & 0.48 & 0.38 & 0.29 \\
Textiles & 0.40 & 0.43 & 0.44 & 0.43 \\
Leather & 0.13 & 0.16 & 0.19 & 0.09 \\
Clothing \& footwear & 0.06 & 0.11 & 0.11 & 0.17 \\
Bricks, pottery & 0.39 & 0.36 & 0.31 & 0.18 \\
Timber, furniture & 0.10 & 0.13 & 0.10 & 0.06 \\
Paper, printing & 0.24 & 0.23 & 0.17 & 0.15 \\
Other manufacturing & 0.34 & 0.29 & 0.19 & 0.10 \\
Average & 0.23 & 0.23 & 0.23 & 0.20 \\
\hline Source: Derived from & & & & \\
\end{tabular}

Source: Derived from Lee, British Regional Employment, using the formula $\Sigma\left(s_{i}-s_{\text {manf }}\right)$ for all positive values where $s_{i}$ is a region's share of employment in industry $i$ and $\mathrm{s}_{\mathrm{manf}}$ is the region's share of all manufacturing employment.

Thomas. ${ }^{19}$ The Census did not report establishment size, but this can be inferred from the returns under the Factory and Workshop Act.

There was quite substantial variation of these characteristics across industries. For example, Table 5 shows that chemicals were intensive in the use of educated workers but textiles were not. Plant size was large in shipbuilding and textiles, which had high localization coefficients, but small in food, drink \& tobacco, leather, and timber and furniture, which were spatially dispersed. The sectors with the biggest linkage effects were bricks and pottery and metal manufactures, which were also the most steam-intensive industries.

Table 6 provides data on regional characteristics including education of the population, agricultural employment, and coal prices. As might be expected, East Anglia had the highest proportion of agricultural employment. From Table 2 it is apparent that it also had relatively high location quotients in food, drink and tobacco, and in leather, which were the two sectors most intensive in the use of agricultural inputs. London \& South East has a much higher proportion of educated workers than

\footnotetext{
${ }^{19}$ Thomas, "Input-Output Approach." Clearly, it is not ideal to assume that the input-output relationships remained unchanged throughout the period 1871-1911. We therefore undertook a robustness check on our results using preliminary estimates from an input-output table for 1851, prepared by Charles Feinstein. In essence, all our econometric results reported below remained intact when these alternative data were used. We are very grateful to Charles Feinstein for sharing his estimates with us and letting us have the opportunity to make this test.
} 
TABLE 5

INDUSTRY CHARACTERISTICS, 1907

\begin{tabular}{lrrrrcr}
\hline \hline & $\begin{array}{c}\text { White- } \\
\text { Collar }\end{array}$ & $\begin{array}{c}\text { Steam } \\
\text { Use }\end{array}$ & $\begin{array}{c}\text { Plant } \\
\text { Size }\end{array}$ & $\begin{array}{c}\text { Intermediate } \\
\text { Input Use }\end{array}$ & $\begin{array}{c}\text { Agricultural } \\
\text { Input Use }\end{array}$ & $\begin{array}{c}\text { Sales to } \\
\text { Industry }\end{array}$ \\
\hline Food, drink \& tobacco & 13.4 & 0.94 & 15.0 & 63.0 & 17.4 & 18.2 \\
Chemicals & 13.8 & 2.44 & 35.9 & 71.0 & 0 & 31.8 \\
Metal manufactures & 5.7 & 7.10 & 67.6 & 79.3 & 0 & 60.4 \\
Mechanical engineering & 8.5 & 2.50 & 50.3 & 51.6 & 0 & 15.0 \\
Instrument engineering & 12.2 & 2.50 & 23.0 & 51.6 & 0 & 15.0 \\
Electrical engineering & 8.5 & 2.50 & 64.8 & 51.6 & 0 & 15.0 \\
Shipbuilding & 5.0 & 1.96 & 164.6 & 57.1 & 0 & 37.6 \\
Vehicles & 5.2 & 1.51 & 62.4 & 52.7 & 0 & 49.8 \\
Metal goods & 7.8 & 1.57 & 32.6 & 54.4 & 0 & 13.2 \\
Textiles & 3.4 & 5.74 & 155.3 & 71.7 & 1.2 & 44.7 \\
Leather & 11.6 & 0.69 & 28.9 & 78.4 & 17.8 & 55.2 \\
Clothing \& footwear & 10.3 & 0.45 & 72.0 & 55.3 & 0 & 4.9 \\
Bricks, pottery & 6.1 & 8.02 & 39.7 & 39.0 & 0 & 92.7 \\
Timber, furniture & 10.1 & 2.54 & 22.8 & 53.9 & 1.5 & 56.2 \\
Paper, publishing & 11.8 & 2.99 & 21.9 & 45.2 & 0.5 & 29.2 \\
Other manufacturing & 10.1 & 2.02 & 27.3 & 52.9 & 0 & 35.0 \\
\hline
\end{tabular}

Sources: White-Collar is the percentage of employees classified by the Census of Production as "Administrative, Clerical and Technical." Steam Use is steam horsepower per $£ 000$ of gross output according to the Census of Production. Plant size is based on employment per establishment based on returns under the Factory \& Workshop Act, Parliamentary Papers, 1909, vol. 79. Input-output data derived from Thomas, "Input-Output Approach," and expressed as a percentage of gross output.

any other region. The industries that used white-collar labor most intensively (chemicals, food, drink and tobacco, and instrument engineering) all have high location quotients in that region. Coal abundance was a feature of northern but not of southern regions. ${ }^{20}$ The steam-powerintensive bricks and pottery and textiles sectors were concentrated in areas with relatively low coal prices. Market potential requires more detailed treatment, which is provided in the next section.

\section{THE EVOLUTION OF MARKET POTENTIAL}

As has been explained, the notion of market potential is important for explanations of industrial location decisions based on New Economic Geography. Market potential varies across locations because of transport costs. To estimate market potential we follow the approach of David Keeble and his collaborators but modify the details to match the circumstances of an earlier transport era. ${ }^{21}$ Market potential depends on

\footnotetext{
${ }^{20}$ We measure coal abundance in terms of relative prices prevailing before the railway age, which gives a clear indication of the traditional areas distinguished in standard accounts of nineteenth-century industrial location.

${ }^{21}$ Keeble et al., "Regional Accessibility."
} 
TABLE 6

REGIONAL CHARACTERISTICS, 1871-1911

\begin{tabular}{|c|c|c|c|c|}
\hline & \multicolumn{2}{|c|}{1871} & \multicolumn{2}{|c|}{1881} \\
\hline & $\begin{array}{l}\text { Agricultural } \\
\text { Employment }\end{array}$ & $\begin{array}{c}\text { Educated } \\
\text { Population }\end{array}$ & $\begin{array}{l}\text { Agricultural } \\
\text { Employment }\end{array}$ & $\begin{array}{l}\text { Educated } \\
\text { Population }\end{array}$ \\
\hline London \& South East & 9.7 & 9.5 & 8.9 & 9.2 \\
\hline East Anglia & 35.0 & 6.1 & 33.3 & 5.1 \\
\hline South West & 22.1 & 6.7 & 21.0 & 5.7 \\
\hline West Midlands & 13.3 & 5.8 & 11.5 & 5.5 \\
\hline East Midlands & 21.7 & 5.1 & 18.1 & 4.8 \\
\hline North West & 5.8 & 6.6 & 4.6 & 6.2 \\
\hline Yorkshire \& Humb. & 8.8 & 5.0 & 7.6 & 5.1 \\
\hline North & 14.2 & 5.8 & 11.9 & 5.1 \\
\hline Wales & 20.1 & 5.4 & 17.1 & 4.5 \\
\hline \multirow[t]{3}{*}{ Scotland } & 22.2 & 5.3 & 16.7 & 7.6 \\
\hline & \multicolumn{2}{|c|}{1891} & \multicolumn{2}{|c|}{1901} \\
\hline & $\begin{array}{l}\text { Agricultural } \\
\text { Employment }\end{array}$ & $\begin{array}{c}\text { Educated } \\
\text { Population }\end{array}$ & $\begin{array}{l}\text { Agricultural } \\
\text { Employment }\end{array}$ & $\begin{array}{c}\text { Educated } \\
\text { Population }\end{array}$ \\
\hline London \& South East & 7.7 & 11.7 & 5.3 & 10.4 \\
\hline East Anglia & 31.7 & 6.9 & 27.4 & 6.8 \\
\hline South West & 18.3 & 7.9 & 15.6 & 7.8 \\
\hline West Midlands & 9.8 & 7.2 & 7.7 & 8.0 \\
\hline East Midlands & 15.5 & 6.1 & 12.3 & 6.5 \\
\hline North West & 4.1 & 7.4 & 3.3 & 8.3 \\
\hline Yorkshire \& Humb. & 6.2 & 6.3 & 5.0 & 7.2 \\
\hline North & 9.9 & 6.6 & 8.0 & 7.0 \\
\hline Wales & 14.1 & 6.4 & 12.1 & 6.8 \\
\hline \multirow[t]{3}{*}{ Scotland } & 14.0 & 8.2 & 11.5 & 9.1 \\
\hline & \multicolumn{2}{|c|}{1911} & & \\
\hline & $\begin{array}{l}\text { Agricultural } \\
\text { Employment }\end{array}$ & $\begin{array}{c}\text { Educated } \\
\text { Population }\end{array}$ & \multicolumn{2}{|c|}{ Coal Prices } \\
\hline London \& South East & 4.9 & 12.4 & \multicolumn{2}{|c|}{252} \\
\hline East Anglia & 27.4 & 6.8 & \multicolumn{2}{|c|}{246} \\
\hline South West & 15.1 & 7.8 & \multicolumn{2}{|c|}{255} \\
\hline West Midlands & 7.3 & 8.0 & \multicolumn{2}{|c|}{90} \\
\hline East Midlands & 11.4 & 6.5 & \multicolumn{2}{|c|}{102} \\
\hline North West & 3.0 & 8.3 & \multicolumn{2}{|c|}{99} \\
\hline Yorkshire \& Humb. & 4.6 & 7.2 & \multicolumn{2}{|c|}{90} \\
\hline North & 7.3 & 7.0 & \multicolumn{2}{|c|}{68} \\
\hline Wales & 10.4 & 6.8 & \multicolumn{2}{|c|}{126} \\
\hline Scotland & 10.6 & 9.1 & \multicolumn{2}{|c|}{91} \\
\hline
\end{tabular}

Sources: Agricultural employment, measured as a percentage of total employment, from Lee, British Regional Employment. Educated population, measured as a percentage of total employment, based on employment in categories 3 (Professional Occupations and their Subordinate Services) and 5 (Merchants, Banking, Insurance, Clerks) from the Census of Population. Coal Prices are based on prices paid by Poor Law Unions, Parliamentary Papers, 1843, vol. 45. 
a distance-deflated sum of neighboring regions' GDP and own GDP and is defined as $P_{i}=\Sigma \mathrm{GDP}_{j} d^{\eta}{ }_{i j}$ where $P_{i}$ is the market potential of region $i$ and $d_{i j}$ is the distance between region $i$ and region $j . \eta$ is traditionally set at $-1 .^{22}$ In implementing this formula we included major trading partners overseas, notably European countries, India, and the United States with GDP converted into $£$ sterling at current exchange rates. ${ }^{23}$

The major problems in estimating market potential for this period lie in obtaining estimates of regional GDP for British regions and in the details of the distance deflation procedure. ${ }^{24}$ We have used estimates for regional GDP recently published by Crafts based on a modified version of the methodology proposed by Frank Geary and Tom Stark. ${ }^{25}$ Inland distances between regions were based on the rail distance between the principal city in each region except where it was cheaper to send goods by coastal shipping, which remained a major component of British transport. ${ }^{26}$ In that case sea miles were converted into rail-equivalent miles for the purpose of distance deflation using estimates of sea transport costs made by Yrjo Kaukiainen. ${ }^{27}$ Rail-equivalent distances to foreign countries were estimated in similar fashion.

Changes in market potential over time can result from either or both of a shift in the spatial distribution of GDP or in relative transport costs. In the period 1871-1911 developments in steamship technology and continuing improvement of railway productivity drove transport costs sharply down. However, as Table 7 reports, after about 1880 costs of sea transport fell by more than those of rail freight. The broad implication of this is that market potential rose relatively more in regions with good access to the sea, such as Scotland, compared with landlocked regions, such as the Midlands.

Table 8 reports estimates for regional market potential for the census years 1871 to 1911 . In all cases, market potential was increasing appreciably at a time of economic growth at home and abroad. From the point of view of location decisions, it is relative market potential that matters. Interestingly, the location quotients for the sectors with the largest linkages

\footnotetext{
${ }^{22}$ We have followed the standard convention of approximating "self-distance" by using the formula $d_{i i}=\sqrt{ }($ area of region $/ \pi)$ which gives a distance value one-third of the radius of a circle of the same area as region $i$; see Keeble et al., "Regional Accessibility."

${ }^{23}$ These estimates were derived from Prados de la Escocura, "International Comparisons."

${ }^{24}$ For an alternative method that can be used to compare early- and late-twentieth-century market potential, see Crafts, "Market Potential."

${ }^{25}$ Geary and Stark, "Examining Ireland's Post-Famine Economic Growth"; full details of the construction of the estimates can be found in Crafts, "Regional GDP."

${ }^{26}$ Armstrong, "Role of Coastal Shipping," estimates that coastal shipping accounted for 59 percent of internal freight ton-miles in 1910. Road haulage was negligible until after the First World War.

${ }^{27}$ Kaukiainen, "How the Price of Distance."
} 
TABLE 7

REAL TRANSPORT COSTS, 1871-1911

\begin{tabular}{rrrr}
\hline \hline \multicolumn{2}{c}{ Coastal Shipping } & \multicolumn{2}{c}{ Rail } \\
\cline { 2 - 3 } $1872-1874$ & 100.0 & 1871 & 100.0 \\
$1879-1880$ & 109.2 & 1880 & 99.1 \\
$1892-1893$ & 84.0 & 1890 & 95.2 \\
$1898-1899$ & 80.4 & 1900 & 90.3 \\
$1911-1913$ & 53.3 & 1911 & 78.2 \\
\hline
\end{tabular}

Sources: Coastal Shipping is based on a distance of 400 miles from Kaukiainen, "Price of Distance"; Rail is based on average rates per ton per mile from Cain, "Private Enterprise," deflated using GDP deflator.

(bricks and pottery and metal manufactures) in the regions with the largest market potential (London and the South East and North West) are all well below one.

There was an obvious change in relative market potential over time in that the Midlands lost ground and London \& South East gained with the result that East Midlands and West Midlands, respectively, fell from 65.0 to 55.9 percent and from 69.1 to 59.7 percent of market potential in London \& South East between 1871 and 1911. However, it should also be noted that Outer Britain (North, Scotland, and Wales) also improved its position. For example, Scotland's market potential rose from 67.5 to 79.3 percent of that in London \& South East between 1871 and 1911. The final column of Table 8 removes the effects of changes in relative transport costs by recalculating 1911 market potential using the railequivalent distances of $1871 .^{28}$ This does not entirely restore the relative position of the landlocked Midlands, however, because regions such as Scotland still gained more over the years 1871-1911 from the formidable growth of the United States.

\section{MODELING THE LOCATION OF INDUSTRY}

In order to analyze regional specialization it is appropriate to employ location theory. There are two obvious possibilities, namely a Heckscher-Ohlin type factor endowment hypothesis or a New Economic Geography market access hypothesis. They both rely on the interaction of regional characteristics with industrial characteristics. The rationale for the emphasis on these interactions lies in the general equilibrium nature of the system. Thus, Heckscher-Ohlin theory predicts that industries

\footnotetext{
${ }^{28}$ Thus sea miles are converted into rail miles using the 1871 relative transport costs, and an 1871 rail mile is taken to be $1 / 0.782$ of a 1911 rail mile. In terms of the exercise subsequently undertaken in Table 11, this scaling factor has no effect, it is only the change in relative costs that matters.
} 
TABLE 8

MARKET POTENTIAL

\begin{tabular}{|c|c|c|c|c|c|c|}
\hline & 1871 & 1881 & 1891 & 1901 & 1911 & $\begin{array}{c}1911 \\
\text { at } 1871 \\
\text { Distances }\end{array}$ \\
\hline \multicolumn{7}{|c|}{ Panel A: $£ 000,000$} \\
\hline London \& South East & 44.3 & 54.6 & 73.4 & 113.9 & 148.1 & 109.4 \\
\hline East Anglia & 31.0 & 37.9 & 52.3 & 80.5 & 108.1 & 77.8 \\
\hline South West & 35.2 & 44.3 & 60.1 & 93.9 & 124.0 & 84.1 \\
\hline West Midlands & 30.6 & 36.9 & 46.5 & 67.5 & 88.4 & 72.5 \\
\hline East Midlands & 28.8 & 34.5 & 43.7 & 62.9 & 82.8 & 68.5 \\
\hline North West & 40.6 & 50.1 & 65.7 & 97.1 & 125.4 & 96.9 \\
\hline Yorkshire \& Humberside & 32.8 & 40.4 & 52.4 & 78.7 & 102.4 & 79.5 \\
\hline North & 31.4 & 40.7 & 56.9 & 91.1 & 119.6 & 73.6 \\
\hline Wales & 33.7 & 43.7 & 59.8 & 94.0 & 125.9 & 83.2 \\
\hline Scotland & 29.9 & 39.6 & 55.5 & 89.4 & 117.5 & 77.0 \\
\hline
\end{tabular}

Panel B: Relative to London \& South East (percentage)

$\begin{array}{lllllll}\text { East Anglia } & 70.0 & 69.4 & 71.3 & 70.7 & 73.0 & 71.1 \\ \text { South West } & 79.5 & 81.1 & 81.9 & 82.4 & 83.7 & 76.9 \\ \text { West Midlands } & 69.1 & 67.6 & 63.4 & 59.3 & 59.7 & 66.3 \\ \text { East Midlands } & 65.0 & 63.2 & 59.5 & 55.2 & 55.9 & 62.6 \\ \text { North West } & 91.6 & 91.8 & 89.5 & 85.3 & 84.7 & 88.6 \\ \text { Yorkshire \& Humberside } & 74.0 & 74.0 & 71.4 & 69.1 & 69.1 & 72.7 \\ \text { North } & 70.9 & 74.5 & 77.5 & 80.0 & 80.8 & 67.3 \\ \text { Wales } & 76.1 & 80.0 & 81.5 & 82.5 & 85.0 & 76.1 \\ \text { Scotland } & 67.5 & 72.5 & 75.6 & 78.5 & 79.3 & 70.4\end{array}$

Note: Data on rail distances were taken from Bradshaw's Railway Guide. The length of sea journeys was obtained from www:dataloy.com/newwebsite/index.php. These were converted into rail-equivalent miles using estimates of the costs of sea transport, taking account both of terminal charges and costs per mile, from Kaukiainen, "Price of Distance" and converting it into a rail equivalent based on the average charge per ton-mile of freight using Cain, "Private Enterprise." Where foreign trade was concerned, an allowance was also made for the cost-equivalent of tariffs using the gravity model estimates in Estevadeordal et al, "Rise and Fall."

Source: Authors' own calculations.

that use a factor of production intensively will tend to locate in regions which are abundantly endowed with that factor whereas New Economic Geography theories predict that the attraction of a region's market potential is greater the more an industry sells to or buys inputs from other industries. These theories should probably be regarded as complementary rather than mutually exclusive, and our empirical analysis will therefore be based on a model recently proposed by Karen MidelfartKnarvik et al., which encompasses them both. ${ }^{29}$

In this model, regions are heterogeneous in various characteristics such as endowments of natural resources and proximity to markets.

${ }^{29}$ Midelfart-Knarvik et al., "Location." 
Similarly, industries differ in their various attributes such as the intensity of use of production factors such as natural resources and skilled labor, and their reliance on intermediate inputs. In equilibrium, all industries cannot be in the same place, but we expect that industries that value a regional characteristic most highly will succeed in locating there. So, for example, we might predict that if cheap coal matters for location, industries that use steam power intensively will gravitate to coal-abundant regions. The interaction between the industrial characteristic, steam power use, and the regional characteristic, coal abundance, is what attracts the industry to the region. If, on the other hand, cheap coal does not matter to industry, then coal abundance should have no attraction for any industry.

The Midelfart-Knarvik et al. model can be written as a reducedform equation to explain a dependent variable that is the share of each region in total British employment in each industry. The independent variables are controls for size, regional characteristics, industrial characteristics, and interactions between these regional and industrial characteristics. In our implementation of the model, we consider the following six interactions: educated population availability and white-collar worker intensity, coal abundance and steam power use, share of agricultural employment and agricultural input use, market potential and plant size, market potential and sales to industry, and market potential and intermediate input use. The first three of these interactions are predicted by the Heckscher-Ohlin theory based on factor endowments; the last three are predicted by New Economic Geography to be activated when transport costs are at the right "intermediate" level such that the pull of centrality kicks in. The model permits evaluation of the relative importance of these various interactions.

The first market-potential interaction hypothesizes that industries operating at relatively large scale will value highly locations relatively close to market demand, which may be true at some but presumably not at all levels of transport costs. The second market-potential interaction based on backward linkages supposes that industries which sell relatively large fractions of their output to other firms rather than final consumers tend to prefer locations relatively close to other producers. The third market-potential interaction predicts that industries which use relatively large amounts of intermediate goods will prefer locations of high market potential. Here the importance of forward linkages is the key but, again, how strongly firms value centrality is likely to depend on transport costs; cheaper inputs have to be traded off against a higher cost of sending goods to final consumers. 
Formally, the basic model can be written as follows

$$
\ln \left(s_{i}{ }^{k}\right)=\alpha \ln \left(\text { pop }_{i}\right)+\phi \ln \left(\operatorname{man}_{i}\right)+\Sigma \beta[j]\left(y[j]_{i}-\psi[j]\right)\left(x[j]^{k}-\chi[j]\right)
$$

where $s_{i}^{k}$ is the share of industry $k$ in region $i$, pop $_{i}$ is the share of British population in region $i$, and $\mathrm{man}_{i}$ is the share of British manufacturing employment in region $i ; y[j]_{i}$ is the level of the $j$ th regional characteristic in region $i ; x[j]^{k}$ is the industry $k$ value of the industry characteristic paired with regional characteristic $j$. Thus, the interaction forces are represented by the terms in the summation. Finally, $\alpha, \phi, \beta[j], \gamma[j]$ and $\chi[j]$ are coefficients to be estimated.

To understand this specification, it is easiest to consider one particu-

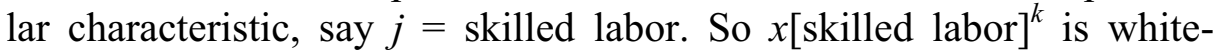
collar worker intensity of industry $k$ and $y$ [skilled labor $]_{i}$ is educatedpopulation abundance of region $i$. The following interpretation can then be given to the model: First, there exists an industry with a level of skilled-labor intensity $\chi$ [skilled labor] such that its location is independent of regional skilled-labor abundance. Second, there exists a level of skilled-labor abundance $\gamma$ [skilled labor] such that the region's share of any industry is independent of the skilled-labor intensity of the industry. Third, if $\beta$ [skilled labor] $>0$, then industries with skilled-labor intensity greater than $\chi$ [skilled labor] will be induced to locate near regions with skilled-labor abundance greater than $\gamma$ [skilled labor]. Estimation of the model will produce the following key parameters for each interaction variable: $\gamma[j], \chi[j]$ and $\beta[j]$ with $j$ running over the six interactions. If, for example, skilled labor is an important determinant of location patterns, we should see a high value of $\beta$ [skilled labor].

Expanding the relationships in the above equation we obtain the estimating equation,

$$
\begin{gathered}
\ln \left(s_{i}{ }^{k}\right)=c+\alpha \ln \left(\text { pop }_{i}\right)+\phi \ln \left(\operatorname{man}_{i}\right)+\Sigma\left(\beta[j] y[j]_{i} x[j]^{k}-\right. \\
\left.\beta[j] \gamma[j] x[j]^{k}-\beta[j] \chi[j] y[j]_{i}\right)
\end{gathered}
$$

This gives a list of independent variables that comprises scaling terms, regional characteristics, industrial characteristics, and interactions between regional and industrial characteristics, as in Table 9. The coefficients of the two size variables, $\alpha$ and $\phi$, are straightforward, and $c$ is a constant term. The estimated coefficients of the regional characteristics, $y[j]$ and the industry characteristics, $x[j]$ are estimates of $-\beta[j] \chi[j]$ and $-\beta[j] \gamma[j]$, respectively, and so are expected to have negative signs. 
The estimated coefficients of the interaction variables, $y[j] x[j]$ are estimates of $\beta[j]$, which are expected to be positive. This is the crucial set of parameters in the model. The relative magnitude and statistical significance of this coefficient on, for example, educated population $\times$ white-collar workers provides us with a measure of how important this factor endowment was in influencing the location of industries in preWorld War I Britain.

For each census year from 1871 to 1911 this equation is estimated by OLS, pooling across industries. The results are reported in Table 9. The intercept is followed by the two terms which pick up regional size effects, then the coefficients of the four regional characteristics, $y[j]$, the six industry characteristics, $x[j]$, and finally the six interaction variables, $\beta[j]$. The coefficients of interest are those on the interaction variables, which capture the joint role of regional and industrial characteristics in the location of industry. Transport costs play a role only if the market potential interactions are a significant determinant of industrial location. If falling transport costs were making market potential considerations matter more, then we should see market potential interactions becoming significant as time goes on.

Of the two size variables, manufacturing employment always has the right sign and is generally quite close to unity. In almost all cases, the coefficients of the regional characteristics have the expected negative signs but are usually statistically insignificant. With respect to the industry characteristics, the coefficients of the variables share of agricultural employment, educated population, and size of establishment have the expected negative signs and are significantly different from zero throughout.

Turning to the key interaction variables, the coefficients relating to interactions involving factor endowments have the correct (positive) signs; educated population $\times$ white-collar workers, coal abundance $\times$ steam power, and agricultural employment $\times$ agricultural input use are significant virtually throughout. This confirms the importance of factor endowment variables in the location of industry. The significance of coal endowments familiar from the traditional literature is also confirmed, but other aspects of factor endowments seem also to have mattered, namely, human capital and land. Moreover, some caution is probably appropriate before these results are taken to be an endorsement of a straightforward Heckscher-Ohlin model of industrial location. For example, proximity to coal may have affected the choice of location of industries such as cotton textiles early in the nineteenth century but later on they may have been anchored in coal-abundant areas by Marshallian external economies of scale.

With respect to the coefficients of the interaction variables involving market potential, market potential $\times$ size of establishment has the expected 
TABLE 9

LOCATION OF BRITISH INDUSTRY REGRESSIONS, 1871-1911

\begin{tabular}{|c|c|c|c|c|c|}
\hline & 1871 & 1881 & 1891 & 1901 & 1911 \\
\hline \multirow[t]{2}{*}{ Constant } & 2.5291 & -1.1308 & 2.3891 & 1.7668 & 2.3529 \\
\hline & $(2.063)$ & $(1.963)$ & $(3.224)$ & $(1.910)$ & $(2.027)$ \\
\hline \multirow[t]{2}{*}{ Population } & 0.4926 & $1.8630^{*}$ & -0.3991 & -0.1754 & -1.0839 \\
\hline & $(0.416)$ & $(1.077)$ & $(3.863)$ & $(0.929)$ & $(1.191)$ \\
\hline \multirow{2}{*}{ Manufacturing employment } & $0.8147 * *$ & $0.4685 * *$ & 0.8476 & $0.8664 * *$ & $0.9834 * *$ \\
\hline & $(0.285)$ & $(0.233)$ & $(0.993)$ & $(0.280)$ & $(0.294)$ \\
\hline \multirow[t]{2}{*}{$\%$ Agricultural employment } & $-0.0232 * *$ & -0.0037 & -0.0329 & -0.0150 & -0.0380 \\
\hline & $(0.014)$ & $(0.020)$ & $(0.060)$ & $(0.021)$ & $(0.034)$ \\
\hline \multirow[t]{2}{*}{$\%$ Educated population } & -0.2509 & $-0.4042 *$ & -0.1590 & -0.2489 & -0.0696 \\
\hline & $(0.227)$ & $(0.252)$ & $(0.560)$ & $(0.227)$ & $(0.253)$ \\
\hline \multirow[t]{2}{*}{ Coal abundance } & $-0.0874^{*}$ & $-0.1810 * *$ & -0.0507 & -0.0486 & -0.0084 \\
\hline & $(0.063)$ & $(0.086)$ & $(0.188)$ & $(0.058)$ & $(0.062)$ \\
\hline \multirow[t]{2}{*}{ Market potential } & $-0.0845^{*}$ & -0.0512 & -0.0101 & 0.0001 & 0.0061 \\
\hline & $(0.055)$ & $(0.052)$ & $(0.055)$ & $(0.018)$ & $(0.014)$ \\
\hline \multirow[t]{2}{*}{ Agricultural input use } & $-0.0233 * *$ & $-0.0225 * *$ & $-0.0197 * *$ & $-0.0216^{* *}$ & $-0.0182 * *$ \\
\hline & $(0.012)$ & $(0.011)$ & $(0.011)$ & $(0.010)$ & $(0.010)$ \\
\hline \multirow[t]{2}{*}{$\%$ White-collar workers } & $-0.3138^{* *}$ & $-0.1797 * *$ & $-0.3439 * *$ & $-0.3446^{* *}$ & $-0.3327 * *$ \\
\hline & $(0.115)$ & $(0.100)$ & $(0.117)$ & $(0.116)$ & $(0.118)$ \\
\hline \multirow[t]{2}{*}{ Steam power use } & 0.0873 & 0.1775 & 0.1880 & 0.2002 & 0.2363 \\
\hline & $(0.109)$ & $(0.121)$ & $(0.110)$ & $(0.121)$ & $(0.121)$ \\
\hline \multirow{2}{*}{ Intermediate input use } & 0.0315 & 0.0300 & 0.0388 & 0.0346 & 0.0358 \\
\hline & $(0.026)$ & $(0.027)$ & $(0.029)$ & $(0.026)$ & $(0.027$ \\
\hline \multirow[t]{2}{*}{ Industry sale } & -0.0026 & 0.0077 & 0.0001 & 0.0035 & 0.0030 \\
\hline & $(0.014)$ & $(0.014)$ & $(0.017)$ & $(0.015)$ & $(0.016)$ \\
\hline \multirow[t]{2}{*}{ Size of establishment } & $-0.0217^{*}$ & $-0.0185^{*}$ & $-0.0326^{* *}$ & $-0.0327 * *$ & $-0.0337 * *$ \\
\hline & $(0.015)$ & $(0.014)$ & $(0.014)$ & $(0.013)$ & $(0.014)$ \\
\hline \multirow{2}{*}{$\begin{array}{l}\text { Agricultural employment } \times \\
\text { agricultural input use }\end{array}$} & $0.0014 * *$ & $0.0015 * *$ & $0.0015 * *$ & $0.0022 * *$ & $0.0019 * *$ \\
\hline & $(0.001)$ & $(0.001)$ & $(0.001)$ & $(0.001)$ & $(0.001)$ \\
\hline \multirow{2}{*}{$\begin{array}{c}\text { Educated population } \times \\
\text { white-collar workers }\end{array}$} & $0.0525 * *$ & $0.0327 * *$ & $0.0459 * *$ & $0.0489 * *$ & $0.0402 * *$ \\
\hline & $(0.017)$ & $(0.015)$ & $(0.015)$ & $(0.016)$ & $(0.014)$ \\
\hline \multirow{2}{*}{$\begin{array}{l}\text { Coal abundance } \times \\
\text { steam power use }\end{array}$} & 0.0079 & $0.0156^{* *}$ & $0.0159 * *$ & $0.0153^{* *}$ & $0.0179^{* *}$ \\
\hline & $(0.009)$ & $(0.009)$ & $(0.008)$ & $(0.009)$ & $(0.009)$ \\
\hline \multirow{2}{*}{$\begin{array}{l}\text { Market potential } \times \\
\quad \text { intermediate input use }\end{array}$} & -0.0008 & -0.0006 & -0.0006 & -0.0004 & -0.0003 \\
\hline & $(0.001)$ & $(0.001)$ & $(0.0005)$ & $(0.0003)$ & $(0.0002)$ \\
\hline \multirow{2}{*}{$\begin{array}{l}\text { Market potential } \times \\
\text { industry sale }\end{array}$} & 0.0001 & -0.0001 & 0.00001 & -0.0001 & -0.00004 \\
\hline & $(0.0004)$ & $(0.0003)$ & $(0.0003)$ & $(0.0002)$ & $(0.00013)$ \\
\hline \multirow{2}{*}{$\begin{array}{l}\text { Market potential } \times \\
\text { size of establishment }\end{array}$} & $0.0006^{*}$ & $0.0004 *$ & $0.0005^{* *}$ & $0.0003 * *$ & $0.0003 * *$ \\
\hline & $(0.0004)$ & $(0.0003)$ & $(0.0002)$ & $(0.0001)$ & $(0.0001)$ \\
\hline Observations & 150 & 160 & 160 & 160 & 160 \\
\hline Adj. $R^{2}$ & 0.57 & 0.59 & 0.63 & 0.66 & 0.65 \\
\hline
\end{tabular}

* indicates significance at the 10 percent level.

** indicates significance at the 5 percent level.

Note: Heteroskedasticity-corrected standard errors are in parenthesis.

positive sign and is statistically significant but the coefficient decreases over time. This indicates that the pull of centrality for increasing-returns industries was weakening over time as transport costs fell. Market potential $\times$ intermediate input use and market potential $\times$ industry sale gener- 
ally have the wrong sign but are always insignificant. Thus, there is no evidence that market potential mattered for location decisions either through upstream or downstream linkage effects even in 1911. This may indicate that transport costs were still too high for these considerations to have an impact on industrial location. ${ }^{30}$ The apparent unimportance of market-potential interactions involving linkage effects may mean that it was not until the motor-transport era that these became relevant for location decisions. The improvement to short-distance freight resulting from road haulage may have encouraged the development of related activities in close proximity, as with the classic case of suppliers to the motor vehicles industry in the West Midlands in the interwar period. ${ }^{31}$

It is possible that our coefficient estimates may suffer from biases caused by potential endogeneity problems, in other words, some of the explanatory variables such as manufacturing employment are determined in the model. Ideally, such problems would call for instrumental variable estimation, but there seems to be no way to implement such an approach. As a crude alternative we have experimented with a regression on lagged values of the regional variables that are time-varying. As can be seen from Appendix Table 1, there is no material change in the estimation results.

A glance back at Table 5 helps to make sense of these results. As was noted earlier, the sectors with the biggest linkage effects (bricks, metal manufactures, and leather) were not among the biggest movers in Table 2. The first two of these industries were the most intensive in the use of steam, and leather was the most intensive user of agricultural inputs. In each case, there was a strong factor-endowment reason for their location, which, in a general equilibrium context, dominated the attraction of market potential. These industries do indeed seem to epitomize the traditional argument that proximity to natural resources was crucial in nineteenth-century location decisions and this seems to have prevailed all the way through to World War I. ${ }^{32}$

Table 10 considers the overall proportion of the variance explained by the various statistically significant interaction variables. This provides two important qualifications to the traditional account of industrial location being heavily influenced by natural resources. First, the

\footnotetext{
${ }^{30}$ Strictly speaking, these results could imply that they may already have been too low but given the finding by Midelfart-Knarvik et al., "Location," pp. 36-37, that these effects started to have an impact in Europe only in the 1990s, we prefer the interpretation in the text.

${ }^{31}$ Lee, Regional Economic Growth, p. 204.

${ }^{32}$ We have explored alternative econometric specifications to estimate our data set by pooling the five sets of cross-section data. Two sets of estimators that we considered are: the pooled least square estimator that represents the average of the within-groups and between-groups estimators; and least square estimators with region or sector specific effects or period specific effects that represent within-group estimators. Each of these leaves the regression results fairly intact. All these results of alternative specifications are available from the authors upon request.
} 
TABLE 10

BETA COEFFICIENTS

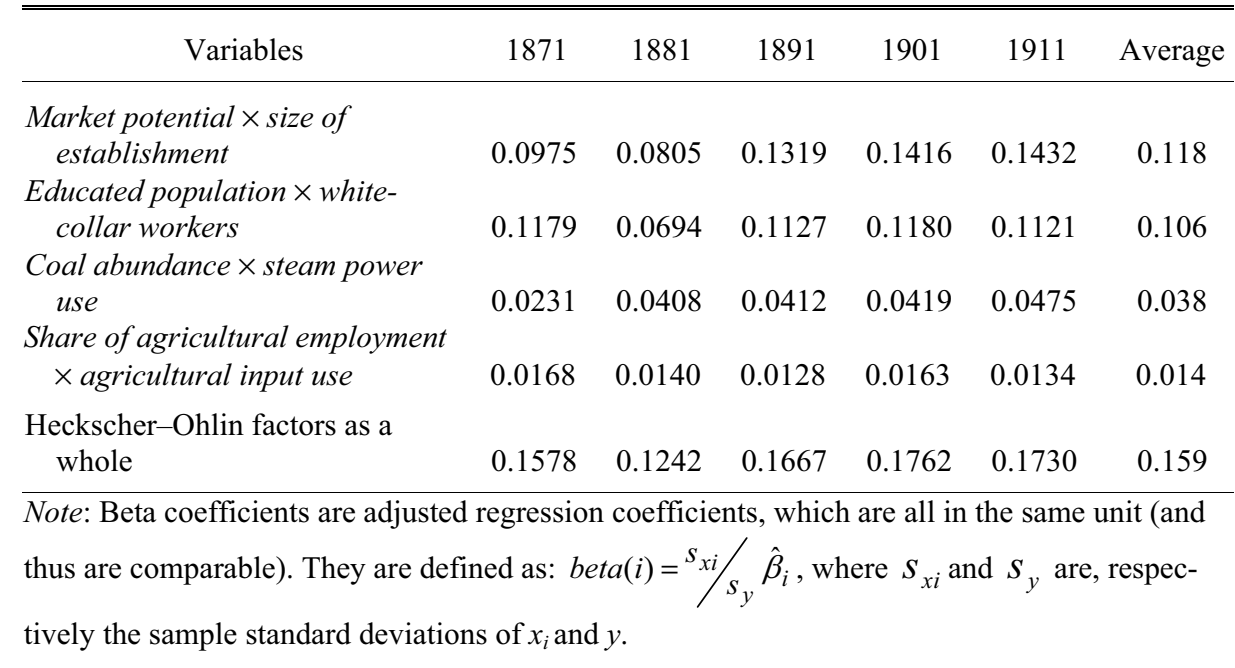

most important factor-endowment interaction is seen to be that of educated population $\times$ white-collar workers. This suggests that the role of human capital in nineteenth-century British industrial location has been underestimated. Second, the single most important interaction variable is market potential $\times$ establishment size, although this contributes less than the sum of the three factor-endowment interactions. In sum, Table 10 suggests that there has been a tendency to oversimplification in discussions of the geography of British industry.

\section{GROWTH EFFECTS OF STEAM-POWERED TRANSPORT}

In previous sections we have shown that the pattern of localization and specialization of British industry changed relatively little in the decades before World War I. We have also found that the most important determinants of industrial location decisions were based on the interaction of regional factor endowments and industrial factor intensities. New Economic Geography forces appear to have been relatively weak in that there was no role for the pull of centrality through linkage effects. There was, however, a role for market potential through the attraction that it offered to industries with large plant size. Accordingly, it is important to ask whether the impact of falls in steam-powered transport costs on market potential would have had much impact on regional shares of manufacturing employment according to these regression estimates. To do this, location of industry as predicted by a regression using actual market potential in 1911 can be compared with the 
TABLE 11

COUNTERFACTUAL EMPLOYMENT IN 1911

\begin{tabular}{|c|c|c|}
\hline \multicolumn{3}{|c|}{ Panel A: Average Absolute Change in Employment Shares } \\
\hline Industry & \multicolumn{2}{|c|}{ Change (percentage points) } \\
\hline Food drink \& tobacco & \multicolumn{2}{|c|}{0.470} \\
\hline Chemicals & \multicolumn{2}{|c|}{0.721} \\
\hline Metal manufacture & \multicolumn{2}{|c|}{0.378} \\
\hline Mechanical engineering & \multicolumn{2}{|c|}{0.218} \\
\hline Instrument engineering & \multicolumn{2}{|c|}{0.438} \\
\hline Electrical engineering & \multicolumn{2}{|c|}{0.182} \\
\hline Shipbuilding & \multicolumn{2}{|c|}{1.361} \\
\hline Vehicles & \multicolumn{2}{|c|}{0.343} \\
\hline Metal goods & \multicolumn{2}{|c|}{0.592} \\
\hline Textiles & \multicolumn{2}{|c|}{1.182} \\
\hline Leather & \multicolumn{2}{|c|}{0.342} \\
\hline Clothing \& footwear & \multicolumn{2}{|c|}{0.540} \\
\hline Bricks, pottery & \multicolumn{2}{|c|}{0.681} \\
\hline Timber, furniture & \multicolumn{2}{|c|}{0.680} \\
\hline Paper, printing & \multicolumn{2}{|c|}{0.534} \\
\hline Other manufacturing & \multicolumn{2}{|c|}{0.563} \\
\hline \multicolumn{3}{|c|}{ Panel B: Change in Manufacturing Employment and All Manufacturing Employment Share } \\
\hline & Employment & Share (percentage points) \\
\hline London \& South East & $+28,888$ & +0.40 \\
\hline East Anglia & $-1,269$ & -0.02 \\
\hline South West & $+17,030$ & +0.23 \\
\hline West Midlands & $-3,589$ & -0.05 \\
\hline East Midlands & $-21,722$ & -0.32 \\
\hline North West & $+9,156$ & +0.13 \\
\hline Yorkshire \& Humberside & $-14,456$ & -0.21 \\
\hline North & $+5,914$ & +0.08 \\
\hline Wales & $+11,679$ & +0.16 \\
\hline Scotland & $+25,778$ & +0.35 \\
\hline
\end{tabular}

Source: counterfactual employment is based on re-estimating the equation of Table 9 with $m a r-$ ket potential $\times$ intermediate input use and market potential $\times$ industry sale omitted and employing the market potential estimates to 1911 using 1871 distances reported in Table 8.

predictions of a regression based on counterfactual market potential in 1911 based on 1871 distances, as reported in Table 8.

Table 11 is based on results obtained by re-estimating the equation omitting the insignificant market potential interaction variables and replacing the actual 1911 market potential variable with the value that would have been observed if transport costs had remained as in 1871 and then comparing the predictions for the dependent variable with those obtained using the original values for market potential on the right-hand side. The general impression that emerges from this exercise is that the impact of transport costs improvements on the location work- 
ing through the remaining interaction of market potential and size of establishment is quite modest.

Looking at panel A of the table, one can see that the overall average change in a region's employment share of an industry is a little under 0.6 percentage points and that inserting the counterfactual market potential with the transport costs change neutralized does not have much effect on the large shifts in employment shares highlighted earlier. Thus the North West's share of textiles and chemicals rose by 5.65 and 4.32 percentage points, respectively, but the changes in the predicted shares are only 0.30 and 0.24 percentage points. Similarly, shipbuilding in the North and Scotland gained 8.94 and 6.33 percentage points, respectively, but the changes in the predicted share are only 1.13 and 0.99 percentage points.

Turning to the impact of the counterfactual market potential on regions, the total changes in employment are on average about 2.4 percent of regional employment and in no case is the change as much as 5 percent. Table 2 shows that the biggest gain in regional share of all manufacturing employment between 1871 and 1911 is 2.37 percentage points in London \& South East but the change in predicted share from inserting the counterfactual market potential variable is only 0.40 percentage points. So, although improvements in steam technology reduced the costs of both water and railway transport quite appreciably between 1871 and 1911, as Table 7 reported, the impact that transport cost reductions had through the interaction of market potential and size of establishment was small — only very marginal shifts in industrial location can be attributed to this variable, according to Table 11 .

In the light of these results, it seems reasonable to argue that there is no reason to believe that estimates of the social savings from railway freight transport need to be revised on account of New Economic Geography-type externalities in the transport-using industries. Nor is there any strong case to argue that steam-powered transport improvements generated substantial TFP spillovers to add to their contribution to growth in the later decades of the nineteenth century. The dramatic relocations of industry that are such a striking feature of Alfred Chandler's account of the rise of mass production and mass distribution as railroads integrated the American domestic market are notable by their absence. So traditional neoclassical approaches to measuring the contribution of better transport to British economic growth are perfectly adequate. $^{33}$

\footnotetext{
${ }^{33}$ Chandler, Visible Hand.
} 


\section{CONCLUSIONS}

Our findings can be summarized in terms of answers to the four questions that we posed in the introduction.

First, the overriding impression is that patterns of the location of industry exhibited marked persistence. This is supported by the summary indices of localization and specialization that were reported in Tables 3 and 4, although, as Table 1 shows, there were changes in regional employment shares. In line with the traditional literature, our regression results suggest that factor endowments were the most important influence on the location of industry and that this acted to anchor activities that were intensive in the use of natural resources, especially coal, in their existing locations. At the same time, the factor endowment hypothesis should not be oversimplified and human capital, in which London \& South East was relatively well endowed, was also an important influence on industrial location.

Second, market potential was affected by the changes in transport costs that were driving globalization forward in the period. In particular, sea transport costs fell relative to those of rail transport and GDP in important markets overseas, such as the United States, increased faster than in the United Kingdom. The implication of this was that market potential in London \& South East and in the regions of Outer Britain (North, Scotland, Wales) grew faster than in the Midlands, as was reported in Table 8. Thus, market potential in West Midlands fell from 69.1 percent to 59.7 percent of that in London \& South East between 1871 and 1911, whereas over the same period in Scotland it rose from 67.5 percent to 79.3 percent of the London \& South East level.

Third, the regressions in Table 9 provide evidence that the pull of centrality affected industrial location decisions through its attraction for industries with relatively large size of establishment. However, as transport costs fell over time the force of this attraction was weakening and industries seem to have become freer to locate on the basis of production rather than distribution costs. There is no evidence that market potential influenced location decisions through linkage effects. This probably reflects both the stronger pull of natural resource considerations and that, in this pre-road-haulage era, transport costs were still too high for these effects to materialize.

Fourth, Table 11 indicates that falling transport costs had only weak effects on the location of industry in the period 1871 to 1911. This means that existing calculations of the impact of steam-powered transport on British economic growth probably do not need to be revised on account of productivity spillover effects. 


\section{Appendix}

The following table displays the results of re-estimating the regressions using tenyear lagged values of the regional characteristics.

APPENDIX TABLE 1

LOCATION OF BRITISH INDUSTRY REGRESSIONS WITH LAGGED EXPLANATORY VARIABLES, 1881-1911

\begin{tabular}{|c|c|c|c|c|}
\hline & 1881 & 1891 & 1901 & 1911 \\
\hline Constant & $\begin{array}{l}1.4974 \\
(2.034)\end{array}$ & $\begin{array}{r}0.3083 \\
(1.870)\end{array}$ & $\begin{array}{l}3.1222 \\
(2.603)\end{array}$ & $\begin{array}{c}1.6688 \\
(1.947)\end{array}$ \\
\hline Population & $\begin{array}{c}0.3696 \\
(0.396)\end{array}$ & $\begin{array}{c}1.1199 \\
(0.915)\end{array}$ & $\begin{array}{c}-1.3801 \\
(2.959)\end{array}$ & $\begin{array}{c}0.2638 \\
(0.872)\end{array}$ \\
\hline Manufacturing employment & $\begin{array}{l}0.8432 * * \\
(0.277)\end{array}$ & $\begin{array}{l}0.4627 * * \\
(0.223)\end{array}$ & $\begin{array}{l}1.1157^{*} \\
(0.754)\end{array}$ & $\begin{array}{l}0.7010^{* *} \\
(0.273)\end{array}$ \\
\hline$\%$ Agricultural employment & $\begin{array}{l}-0.0209^{*} \\
(0.013)\end{array}$ & $\begin{array}{c}-0.0219 \\
(0.020)\end{array}$ & $\begin{array}{c}-0.0459 \\
(0.052)\end{array}$ & $\begin{array}{c}-0.0125 \\
(0.021)\end{array}$ \\
\hline$\%$ Educated population & $\begin{array}{c}-0.2392 \\
(0.226)\end{array}$ & $\begin{array}{r}-0.2864 \\
(0.237)\end{array}$ & $\begin{array}{c}-0.0005 \\
(0.485)\end{array}$ & $\begin{array}{l}-0.3295^{*} \\
(0.248)\end{array}$ \\
\hline Coal abundance & $\begin{array}{c}-0.0670 \\
(0.059)\end{array}$ & $\begin{array}{l}-0.1370 * * \\
(0.072)\end{array}$ & $\begin{array}{c}0.0132 \\
(0.133)\end{array}$ & $\begin{array}{l}-0.0742^{*} \\
(0.055)\end{array}$ \\
\hline Market potential & $\begin{array}{c}-0.0472 \\
(0.054)\end{array}$ & $\begin{array}{r}-0.0387 \\
(0.047)\end{array}$ & $\begin{array}{r}0.0035 \\
(0.040)\end{array}$ & $\begin{array}{c}-0.0033 \\
(0.018)\end{array}$ \\
\hline Agricultural input use & $\begin{array}{l}-0.0214^{* *} \\
(0.012)\end{array}$ & $\begin{array}{l}-0.0219 * * \\
(0.011)\end{array}$ & $\begin{array}{l}-0.0169 * \\
(0.011)\end{array}$ & $\begin{array}{l}-0.0191^{* *} \\
(0.010)\end{array}$ \\
\hline$\%$ White-collar workers & $\begin{array}{l}-0.2946^{* *} \\
(0.116)\end{array}$ & $\begin{array}{l}-0.2021 * * \\
(0.097)\end{array}$ & $\begin{array}{l}-0.3397 * * \\
(0.110)\end{array}$ & $\begin{array}{l}-0.3473^{* *} \\
(0.123)\end{array}$ \\
\hline Steam power use & $\begin{array}{c}0.1092 \\
(0.111)\end{array}$ & $\begin{array}{c}0.2300 \\
(0.116)\end{array}$ & $\begin{array}{r}0.1771 \\
(0.117)\end{array}$ & $\begin{array}{c}0.2614 \\
(0.122)\end{array}$ \\
\hline Intermediate input use & $\begin{array}{c}0.0441 \\
(0.026)\end{array}$ & $\begin{array}{r}0.0285 \\
(0.027)\end{array}$ & $\begin{array}{c}0.0381 \\
(0.027)\end{array}$ & $\begin{array}{c}0.0359 \\
(0.028)\end{array}$ \\
\hline Industry sale & $\begin{array}{c}-0.0033 \\
(0.014)\end{array}$ & $\begin{array}{c}0.0043 \\
(0.014)\end{array}$ & $\begin{array}{c}0.0009 \\
(0.015)\end{array}$ & $\begin{array}{r}0.0009 \\
(0.016)\end{array}$ \\
\hline Size of establishment & $\begin{array}{l}-0.0224 * \\
(0.015)\end{array}$ & $\begin{array}{l}-0.0205^{*} \\
(0.015)\end{array}$ & $\begin{array}{l}-0.0338^{* *} \\
(0.015)\end{array}$ & $\begin{array}{l}-0.0342 * * \\
(0.014)\end{array}$ \\
\hline $\begin{array}{l}\text { Agricultural employment } \times \\
\text { agricultural input use }\end{array}$ & $\begin{array}{l}0.0012 * * \\
(0.0006)\end{array}$ & $\begin{array}{l}0.0015^{* *} \\
(0.0006)\end{array}$ & $\begin{array}{l}0.0014 * * \\
(0.0006)\end{array}$ & $\begin{array}{l}0.0019 * * \\
(0.0006)\end{array}$ \\
\hline $\begin{array}{l}\text { Educated population } \times \\
\text { white-collar workers }\end{array}$ & $\begin{array}{l}0.0501^{* *} \\
(0.017)\end{array}$ & $\begin{array}{l}0.0342 * * \\
(0.014)\end{array}$ & $\begin{array}{l}0.0441^{* *} \\
(0.014)\end{array}$ & $\begin{array}{l}0.0491^{* *} \\
(0.017)\end{array}$ \\
\hline $\begin{array}{l}\text { Coal abundance } \times \\
\text { steam power use }\end{array}$ & $\begin{array}{c}0.0099 \\
(0.009)\end{array}$ & $\begin{array}{l}0.0192 * * \\
(0.009)\end{array}$ & $\begin{array}{l}0.0133^{*} \\
(0.009)\end{array}$ & $\begin{array}{l}0.0197 * * \\
(0.009)\end{array}$ \\
\hline $\begin{array}{l}\text { Market potential } \times \\
\quad \text { intermediate input use }\end{array}$ & $\begin{array}{c}-0.0012 \\
(0.001)\end{array}$ & $\begin{array}{c}-0.0006 \\
(0.001)\end{array}$ & $\begin{array}{l}-0.0006 \\
(0.0004)\end{array}$ & $\begin{array}{l}-0.0004 \\
(0.0003)\end{array}$ \\
\hline $\begin{array}{l}\text { Market potential } \times \\
\quad \text { industry sale }\end{array}$ & $\begin{array}{c}0.0002 \\
(0.0004)\end{array}$ & $\begin{array}{c}-0.00009 \\
(0.0003)\end{array}$ & $\begin{array}{c}-0.00003 \\
(0.0003)\end{array}$ & $\begin{array}{c}-0.00003 \\
(0.0002)\end{array}$ \\
\hline $\begin{array}{l}\text { Market potential } \times \\
\quad \text { size of establishment }\end{array}$ & $\begin{array}{c}0.0006^{*} \\
(0.0004)\end{array}$ & $\begin{array}{c}0.0004^{*} \\
(0.0003)\end{array}$ & $\begin{array}{l}0.0005^{* *} \\
(0.0002)\end{array}$ & $\begin{array}{l}0.0004 * * \\
(0.0002)\end{array}$ \\
\hline $\begin{array}{l}\text { Observations } \\
\text { Adj. } R^{2}\end{array}$ & $\begin{array}{l}160 \\
0.59\end{array}$ & $\begin{array}{l}160 \\
0.62\end{array}$ & $\begin{array}{l}160 \\
0.66\end{array}$ & $\begin{array}{l}160 \\
0.59\end{array}$ \\
\hline
\end{tabular}

* indicates significance at the 10 percent level.

** indicates significance at the 5 percent level.

Notes: Heteroskedasticity-corrected standard errors are in parenthesis. 


\section{REFERENCES}

Armstrong, "The Role of Coastal Shipping in UK Transport: An Estimate of Comparative Traffic Movements in 1910." Journal of Transport History 8, no. 2 (1987): 164-78.

Cain, Peter J. "Private Enterprise or Public Utility? Output, Pricing and Investment on English and Welsh Railways, 1870-1914." Journal of Transport History 1, no. 1 (1980): 9-28.

Chandler, Alfred D. The Visible Hand: The Managerial Revolution in American Business. Cambridge, MA: The Belknap Press, 1977.

Crafts, Nicholas. "Steam as a General Purpose Technology: A Growth Accounting Perspective.” Economic Journal 114, no. 495 (2004): 338-51.

. "Market Potential in British Regions, 1871-1931." Regional Studies 39, no. 9 (2005): 1159-66.

"Regional GDP in Britain, 1871-1911: Some Estimates." Scottish Journal of Political Economy 52, no. 1 (2005): 54-64.

Dennison, Stanley. The Location of Industry and the Depressed Areas. London: Oxford University Press, 1939.

Estevadeordal, Antoni, Brian Frantz, and Alan M. Taylor. "The Rise and Fall of World Trade, 1870-1939." Quarterly Journal of Economics 118, no. 2 (2003): 359-407.

Geary, Frank, and Tom Stark. "Examining Ireland's Post-Famine Economic Growth Performance." Economic Journal 112, no. 7 (2002): 919-35.

Gourvish, Terence R. Railways and the Economy, 1830-1914. London: Macmillan, 1980.

Hawke, Gary R. Railways and Economic Growth in England and Wales, 1840-1870. Oxford: Clarendon Press, 1970.

Hudson, Patricia. "The Regional Perspective." In Regions and Industries: A Perspective on the Industrial Revolution in Britain, edited by Patricia Hudson, 5-38. Cambridge: Cambridge University Press, 1989.

Hume, John R., and Miles Oglethorpe. "Engineering." In Atlas of Industrializing Britain, 1780-1914, edited by John Langton and Robert J. Morris, 136-39. London: Methuen, 1986.

Kaukiainen, Yrjo. "How the Price of Distance Declined: Ocean Freights for Grain and Coal from the 1870 s to 2000." mimeo, Department of History, University of Helsinki.

Keeble, D., P. L. Owens, and C. Thompson. "Regional Accessibility and Economic Potential in the European Community." Regional Studies 16, no. 6 (1982), 419 32.

Kim, Sukkoo. "Expansion of Markets and the Geographic Distribution of Economic Activities: The Trends in U.S. Regional Manufacturing Structure, 1860-1987." Quarterly Journal of Economics 110, no. 4 (1995): 881-908.

. "Economic Integration and Convergence: U.S. Regions, 1840-1987." This JOURNAL 58, no. 3 (1998): 659-83.

"Regions, Resources, and Economic Geography: Sources of U.S. Regional Comparative Advantage, 1880-1987." Regional Science and Urban Economics 29, no. 1 (1999): 1-32.

Krugman, Paul. Geography and Trade. Cambridge, MA: MIT Press, 1991.

Langton, John, and Robert J. Morris. "Introduction." In Atlas of Industrializing Britain, 1780-1914, edited by John Langton and Robert J. Morris, xxii-xxx. London: Methuen, 1986. 
Lee, Clive H. Regional Economic Growth in the United Kingdom since the 1880s. London: Allen and Unwin, 1971.

British Regional Employment Statistics, 1841-1971. Cambridge: Cambridge University Press, 1979.

Midelfart-Knarvik, Karen H., Henry G. Overman, Stephen J. Redding, et al. "The Location of European Industry." Economic Papers No. 142 European Commission. Brussels, 2000.

Pollard, Sidney. Peaceful Conquest. Oxford: Oxford University Press, 1981.

Prados de la Escosura, Leandro. "International Comparisons of Real Product, 1820 1990: An Alternative Dataset." Explorations in Economic History 37, no. 1 (2000): $1-41$.

Richardson, Jeremy D., and Peter Smith. "Sectoral Growth across U.S. States: Factor Content, Linkages, and Trade.” NBER Working Paper No. 5094 (1995).

Thomas, Mark. "An Input-Output Approach to the British Economy, 1890-1914." D. Phil. Thesis, University of Oxford, 1984.

Venables, Anthony J. "Equilibrium Locations of Vertically Linked Industries." International Economic Review 37 (1996): 341-59.

Venables, Anthony J., and Michael Gasiorek. "The Welfare Implications of Transport Improvements in the Presence of Market Failure." In Reports to the Standing Advisory Committee on Trunk Road Assessment, DETR, 7-58. London: DETR.

von Tunzelmann, G. Nicholas. "Coal and Steam Power." In Atlas of Industrializing Britain, 1780-1914, edited by John Langton and Robert J. Morris, 72-79. London: Methuen, 1986. 